\title{
A Full-Frontal History of the Romanov Dynasty: Pictorial "Political Pornography" in Pre-Reform Russia
}

\section{ERNEST A. ZITSER}

\begin{abstract}
A French witticism plays on words and sparkles with felicitous word choices. A Russian one - with the apt employment of contradictory propositions. The French joke for the ear, the Russians for the eyes. All our jokes are illustrated ( $v$ litsakh). Almost every Russian joke can be transposed into a caricature (perelozhit' v karikaturu).
\end{abstract}

Prince P. A. Viazemskii, Zapisnye knizhki: 1813-1848

\begin{abstract}
$\mathrm{W}$ hile the study of Russian graphic satire has a long and distinguished history, there are still only a handful of works on Russian erotic art, and only one scholarly discussion of what Boris Kolonitskii, following Lynn Hunt, has called Russian "political pornography," that is, the use of sexually explicit imagery for defamatory and even revolutionary ends. ${ }^{1}$ Part of the reason for this lacuna is the heretofore widespread reluctance to take pornography seriously as a topic of historical research. ${ }^{2}$ A much more substantive reason is the relative
\end{abstract}

The author expresses appreciation to the Warner Fund at the University Seminars at Columbia University for their help in publication. The ideas presented have benefited from discussions in the University Seminar on Slavic History and Culture. Thanks also to the participants of the 2007-8 John Hope Franklin Humanities Institute Seminar, Duke University; the Centre for Russian Studies Seminar, University College London; the Duke/UNC-Chapel Hill Center for Slavic, Eurasian, and East European Studies; and especially to Pamela Kachurin, my wife and personal art historian, whose support and encouragement made it all possible.

${ }^{1}$ B. I. Kolonitskii, “'Politicheskia pornografiia' i desakralizatsiia vlasti v gody Pervoi mirovoi voiny (slukhi i massovaia kul'tura)," in 1917 god v sud'bakh Rossii i mira: Oktiabr'skaia revoliutsiia: Ot novykh istochnikov k novomu osmysleniiu, ed. S. V. Tiutiukin (Moscow, 1998), 67-81; Kolonitskii and Orlando Figes, Interpreting the Russian Revolution: The Language and Symbols of 1917 (New Haven, 1999), 9-29; and Kolonitskii, "Tragicheskaia erotika": Obrazy imperatorskoi sem'i v gody Pervoi mirovoi voiny (Moscow, 2010), 14, 33543, 352-70. Kolonitskii's approach is explicitly based on the work of historians of the French Revolution, particularly Lynne Hunt, The Family Romance of the French Revolution (Berkeley, 1992); and idem, "Pornography and the French Revolution," in The Invention of Pornography: Obscenity and the Origins of Modernity, 1500-1800, ed. Lynn Hunt (New York, 1993), 301-39.

${ }^{2}$ Scholarly study of the topic was pioneered by historians of early modern France and England, such as Robert Darnton, The Literary Underground of the Old Regime (Cambridge, MA, 1982); and Iain McCalman,

The Russian Review 70 (October 2011): 557-83

Copyright 2011 The Russian Review 
paucity of native visual sources, which begin to appear in print only at the beginning of the twentieth century. While the tradition of inventing pictorial "pasquinades" (paskvili) of high-standing political figures was not unknown in late-eighteenth-century Russia, no examples of such original, hand-drawn images appear to have survived to the present. ${ }^{3}$ Indeed, until recently, to get a sense of what these "satirical pictures" may have looked like, scholars had to rely on scattered written descriptions, such as those recorded in the autobiographical notes of A. T. Bolotov, or the gossipy anecdotal histories of Georg Adolf Wilhelm von Helbig and Charles François Philibert Masson. Even then, aside from fleeting references to a case involving two Russian ladies-in-waiting at the court of Catherine the Great, there was very little concrete evidence for the domestic production and circulation of obscene "caricatures" in which a Russian monarch was the direct object of ridicule. ${ }^{4}$

This is one of the reasons why the recent discovery of a "set of five unique watercolors depicting eighteenth-century Russian emperors and empresses in flagrante delicto" merits some serious scholarly attention. ${ }^{5}$ The series of undated and anonymous erotic drawings in question was acquired in 2001 by the curators of the former Slavic and Baltic Division of the New York Public Library (NYPL) from a Russian-born antiquarian book dealer who specializes in objects of Imperial and elite provenance. ${ }^{6}$ It was first displayed to the

Radical Underworld: Prophets, Revolutionaries, and Pornographers in London, 1795-1840 (New York, 1988). The focus has recently expanded beyond European political radicalism, and now includes the study of visual, material, and mass culture in a global perspective. See Lisa Z. Sigel, "Introduction: Issues and Problems in the History of Pornography," in International Exposure: Perspectives on Modern European Pornography, 18002000, ed. Lisa Z. Sigel (New Brunswick, NJ, 2005), 1-26. In Anglophone Russian studies the pioneering work is William Hugh Hopkins, “The Development of 'Pornographic' Literature in Eighteenth- and Early NineteenthCentury Russia” (Ph.D. diss., Indiana University, 1977). See also M. Levitt and A. L. Toporkov, eds., Eros and Pornography in Russian Culture/Seks i erotika v russkoi traditsionnoi kul'ture (Moscow, 1996).

${ }^{3}$ For a discussion of eighteenth-century paskvili, both literary and pictorial, see "Pis'mo imperatritsy Ekateriny II-i k P. P. Konovitsynu, 1785 (soobshcheno A. A. Martynovym)," Russkii arkhiv 15:3 (1877): 333; G. Gukovskii and V. Orlov, "Podpol'naia poeziia 1770-1800 godov," Literaturnoe nasledstvo 9-10 (1933): 5-98; K. V. Sivkov, "Podpol'naia politicheskaia literatura v Rossii v poslednei treti XVIII v.," Istoricheskie zapiski 19 (1946): 63-101; and E. A. Nekrasova, "U istokov russkoi politicheskoi karikatury," Nauchnye doklady vysshei shkoly: Istoricheskie nauki 3 (1958): 21-26.

${ }^{4}$ A. T. Bolotov, Pamiatnik pretekshikh vremen, ili, Kratkie istoricheskie zapiski o byvshikh proisshestviiakh i nosivshikhsia v narode slukhakh, 1796 , ed. T. G. Tetekina (1875; reprint ed. Kaliningrad, 2004), 116-17 (No. 264: "O satiricheskikh kartinakh [fevral']"); V. A. Vil'basov, "Russkie izbranniki i sluchainye liudi v XVIII v., sostavil Gel'vig, sekretar' saksonskogo posol'stva pri Ektarine II," Russkaia starina 53 (JanuaryMarch 1887): 548-49 (translation of Georg Adolf Wilhelm von Helbig's Russische Günstlinge [Tübingen, 1809]); Charles François Philibert Masson, Mémoires secrets sur la Russie, et particulièrement sur la fin du règne de Catherine II, et sur celui de Paul I (Paris, 1804), 3:391-93.

${ }^{5}$ New York Public Library (NYPL), Slavic Reserve 01-1316. The quotation in the text comes from the caption accompanying a color reproduction of one of the watercolors in this set (that of Catherine the Great). See Cynthia H. Whittaker, E. Kasinec, and Robert H. Davis, Russia Engages the World, 1453-1825 (Cambridge, MA, 2003), 180 (No. 107) Another watercolor (depicting Anna Ioannovna) has been reproduced in Visual Resources from Russia and Eastern Europe in the New York Public Library: A Checklist (New York, 2008), 35,43 (no. 204).

"Antiquarian" Alex Rabinovich, of Jackson Heights, NY, is listed in Andrzej Klossowski and Wojciech Zalewski, Dealers of Polish and Russian Books Active Abroad 1918 to Present: A Contribution to the History of Book Trade (Stanford, 1990), 174. For a brief autobiography see the preface to Alexander Rabinovich, Books and Artifacts (16th-20th centuries): From the Personal and Palace Libraries of the Romanov Dynasty, and the Russian Elite: A Catalogue/Knigi i rukopisi iz chastnykh $i$ dvortsovykh sobranii dinasti Romanovykh i Rossiiskikh aristokraticheskikh domov (16-20 vv.): Katalog kolektsii (New York, 2005). 
general public in 2003, during a successful, long-running exhibit celebrating both the tercentenary of the founding of St. Petersburg and post-Soviet Russia's re-engagement with the world.7 All five watercolors in this series of "folded" or "double pictures" (skladnye or dvoinye kartinki) were drawn on unmarked, hand-pressed sheets of medium-weight, wove paper dating from the late eighteenth/early nineteenth century. ${ }^{8}$ Each piece of paper measured $18 \mathrm{~cm} \times 29 \mathrm{~cm}$ and had been carefully folded in three to create a set of doors, guarded by Russian imperial sentries, like the one depicted in plate 10, smartly dressed in periodspecific military uniforms. Opening these side doors revealed a central scene depicting five successive eighteenth-century Russian monarchs and their lovers in the act of copulation. The fornicating couples, who were either identified in the inscriptions that accompany the drawings or recognizable from their official portraits, are none other than: Peter the Great (the founder of Imperial Russia) and his low-born, foreign wife, Marta Skavronskaia (the future Empress Catherine I); Empress Anna Ioannovna (Peter's niece) and her Baltic German lover, Ernst Johann von Bühren (Biron); Empress Elizaveta Petrovna (Peter's daughter) and her Ukrainian lover, Aleksei Razumovskii; Empress Catherine II (neé Sophia Augusta Frederica of Anhalt-Zerbst-Dornburg) and her Russian paramour, Prince Grigorii Potemkin; and, finally, Emperor Paul I (Catherine II's son from another one of her extramarital affairs) and his second wife, Empress Mariia Fedorovna (neé Sophie Dorothea of Württemberg), with whom Paul fathered the entire male line of nineteenth-century Russian heirs to the throne. ${ }^{9}$ In fact, only three Romanovs were missing from this list of reigning, eighteenthcentury Russian monarchs: the infant emperor Ioann Antonovich (Ivan VI, r. 1740-41) and the two short-lived grandsons of Peter the Great, Peter II (r. 1727-30) and Peter III (r. 1761-62) - although it could be argued that the series creators' punning characterization of Catherine II as a "great wife/woman" (velikaia zhena) may, in fact, have been intended as an oblique reference to her cuckolded husband (Peter III), who was deposed and killed in the 1762 court coup that brought her to power.

The obverse of the "doors" on four of the five watercolors in the series contained profanity-laden epigrams, written using a goose-quill pen dipped in iron-gall ink (see plates 1-4), while the fifth in the series, depicting Paul I and Mariia Fedorovna, had no text (see plate 5$):{ }^{10}$

${ }^{7}$ The show was on view from October 3, 2003 to January 31, 2004, and in a revised configuration from February 20 to May 22, 2004, at the NYPL's Humanities and Social Sciences Library. See Russia Engages the World, 1453-1825 at http://russia.nypl.org/home.html (last accessed March 5, 2008).

${ }^{8}$ The following analysis is based on the results of an examination conducted by Sarah Reidell, NYPL Associate Conservator for Books and Paper, which are summarized in an email message sent to the author on December 14, 2006, by Senior Librarian Hee-Gwone Yoo. See NYPL Slav. Reserve 01-1316. On "double-" or "folded drawings" see S. V. Denisenko, Eroticheskie risunki Pushkina (Moscow, 1997), 24.

${ }^{9}$ A comparison of the portraits of Mariia Fedorovna with those of Paul's two Russian lovers, Anna Lopukhina and Ekaterina Nelidova, confirms that in the watercolor the emperor's sexual partner is, in fact, his wife. See D. A. Rovinskii, Podrobnyi slovar' russkikh gravirovannykh portretov (St. Petersburg, 1889), 1:1049-54 (Mariia Fedorovna in profile); and en face in Grand Duke Nikolai Mikhailovich, Russkie portrety XVIII $i$ XIX stoletii, 5 vols. (St. Petersburg, 1905-9), 1:no. 27, also available at http://digitalgallery.nypl.org/nypldigital/id?1230454. For Nelidova see ibid., vol. 3 (no. 31), available at http://digitalgallery.nypl.org/nypldigital/id?1230658. For Lopukhina see ibid., vol. 1 (no. 66: Princess Gagarina née Anna Lopukhina), available at http:// digitalgallery.nypl.org/nypldigital/id?1230485. All three last accessed March 5, 2008.

${ }^{10}$ I am grateful to Yekaterina Shraga, Processing Archivist, Bakhmeteff Archive, Columbia University, for her assistance in deciphering the inscriptions on the NYPL watercolors. 
Plate 1 [Peter I and Catherine I]

Велик Ебака сей

Ебал чухонок немок придворных гордых дам ебал крестьянских девок Он был в делах велик изъездил всю Европу на всякий лад ебал любил же через жопу Он всех ебать привык придворных недот[рог?] крестьян попов холопов мещан и разных вс[ех?] Российских остолопо[в]

Он отдыха не знал И вот в часы досуги он чисткой занял[ся?] пизды своей супруги

\section{Plate 2 [Biron and Anna Ioannovna]}

Сей знатной господин

большой имеет чин

заслугою своей

гордился перед нами

Бирон сей господин

и он вот перед вами

Внук конюха

и сам барейтор

он дурой Анною

в конец был возлюблен

Ебая Анну [он?] Россию

еб во всю

но после восприял

кару за то всию
This Great Fornicator

screwed Finnish and German women, haughty court ladies

as well as [Russian] serf girls.

Great in deeds, he traveled all over Europe, fucking in all manner of ways, but was especially fond of doing it in the ass. He got accustomed to fucking everyone over courtly touch-me-nots, peasants, priests, slaves, merchants, and all kinds of other Russian blockheads.

He didn't know what rest was, and even here, in his leisure time, he busies himself

by cleaning out his wife's cunt.

This distinguished gentleman

holds a lofty rank.

He prided himself

on his merits over us.

This gentleman's name is Biron and here he is in front of you.

Although he was the grandson of a groom, and had himself served as Bareiter, in the end he became the paramour of that fool Anna.

Screwing Anna, he really fucked Russia over.

However, he did get his come-uppance for it all in the end.

\section{Plate 3 [Elizaveta Petrovna and Razumovskii]}

Вот как хохлы за хвост форутну ловят с Лемишких казаков в прдиворны певуны

а далее в фелтмаршалы выходят
This is how the Ukes catch fortune by the tail Lemko Cossacks become court singers, and are then promoted to field marshals. 


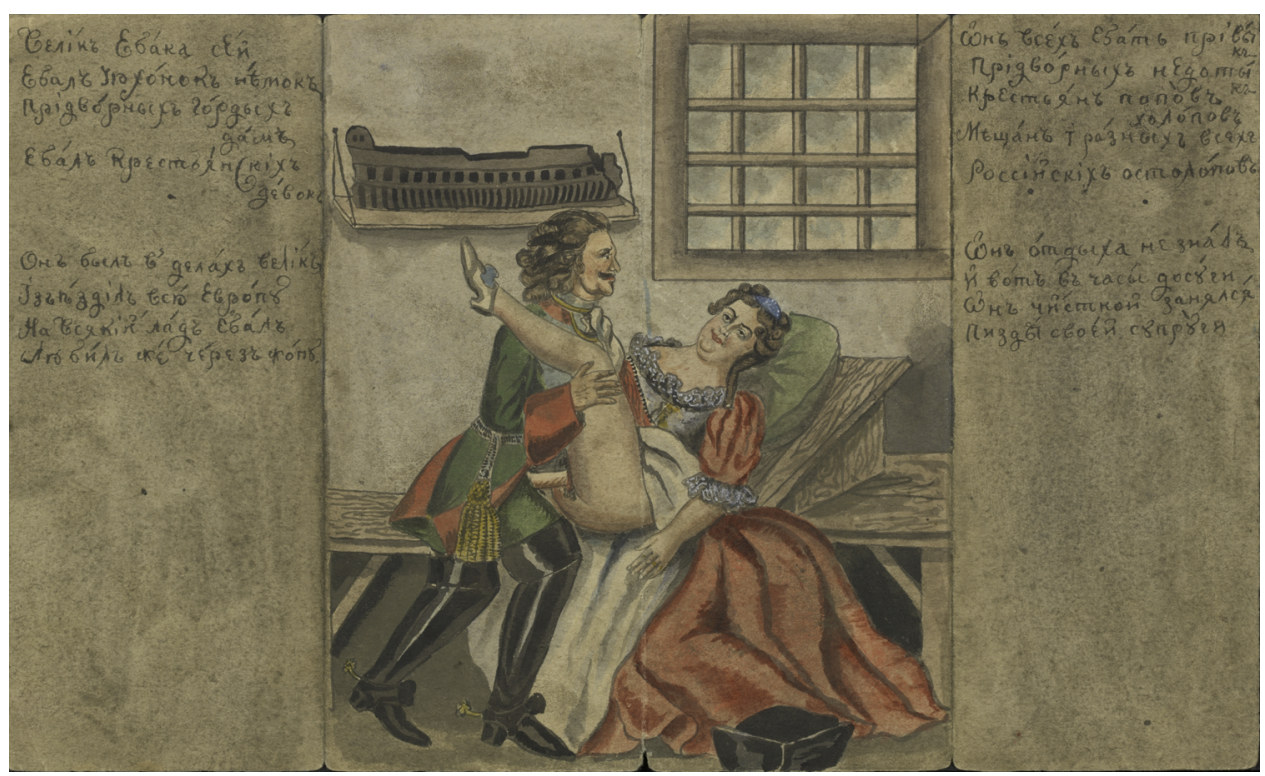

Plate 1 Russian, Anonymous. [Emperor Peter I and Marta Skavronskaia (Empress Catherine I)]. "Folded" or "double picture." First half of the nineteenth century. Watercolor and iron-gall ink on unmarked, hand-pressed sheet of medium-weight, wove paper. 18 x $29 \mathrm{~cm}$. NYPL Slav. Reserve 01-1316. Courtesy New York Public Library.

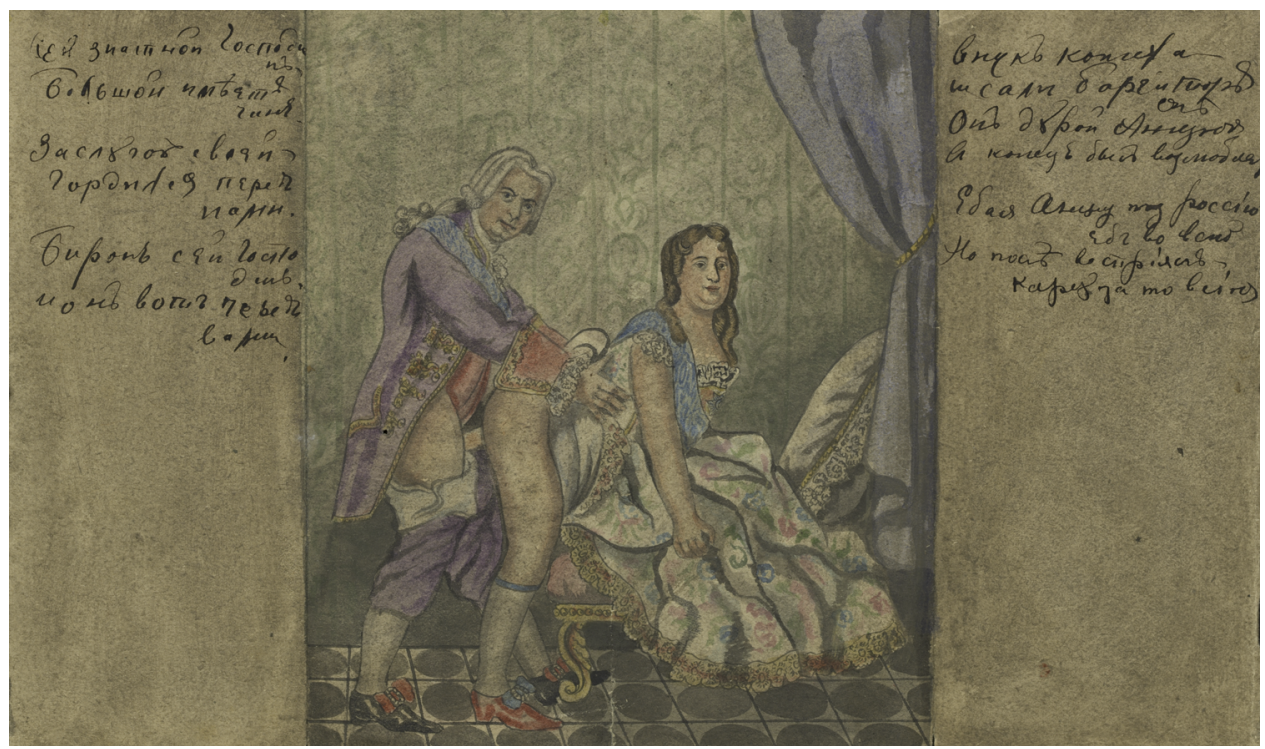

Plate 2 Russian, Anonymous. [Ernst Johann von Bühren (Biron) and Empress Anna Ioannovna]. "Folded" or "double picture." First half of the nineteenth century. Watercolor and iron-gall ink on unmarked, hand-pressed sheet of medium-weight, wove paper. 18 x $29 \mathrm{~cm}$. NYPL Slav. Reserve 01-1316. Courtesy New York Public Library. 


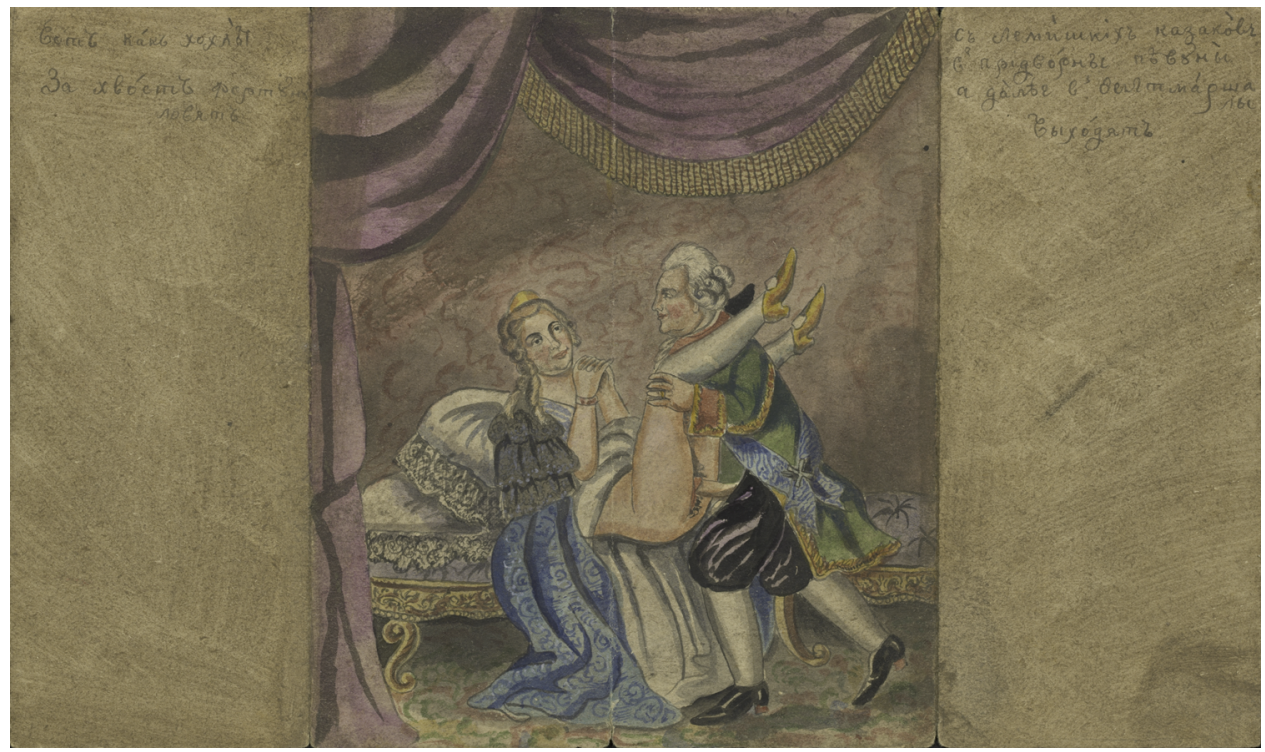

Plate 3 Russian, Anonymous. [Empress Elizaveta Petrovna and Aleksei Razumovskii]. "Folded" or "double picture." First half of the nineteenth-century. Watercolor and iron-gall ink on unmarked, hand-pressed sheet of medium-weight, wove paper. 18 x $29 \mathrm{~cm}$. NYPL Slav. Reserve 01-1316. Courtesy New York Public Library.

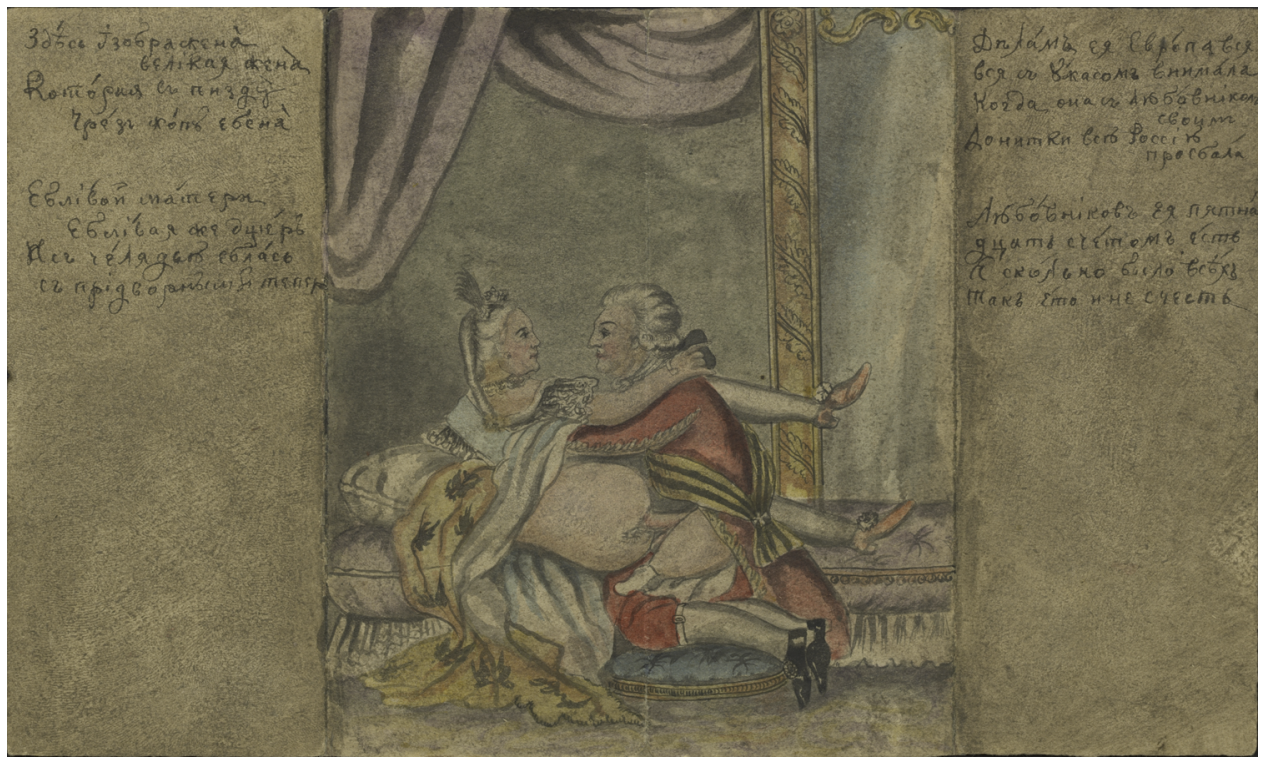

Plate 4 Russian, Anonymous. [Empress Catherine II (Sophia Augusta Frederica of Anhalt-ZerbstDornburg) and Prince Grigorii Potemkin]. "Folded" or "double picture." First half of the nineteenth century. Watercolor and iron-gall ink on unmarked, hand-pressed sheet of medium-weight, wove paper. 18 x $29 \mathrm{~cm}$. NYPL Slav. Reserve 01-1316. Courtesy New York Public Library. 


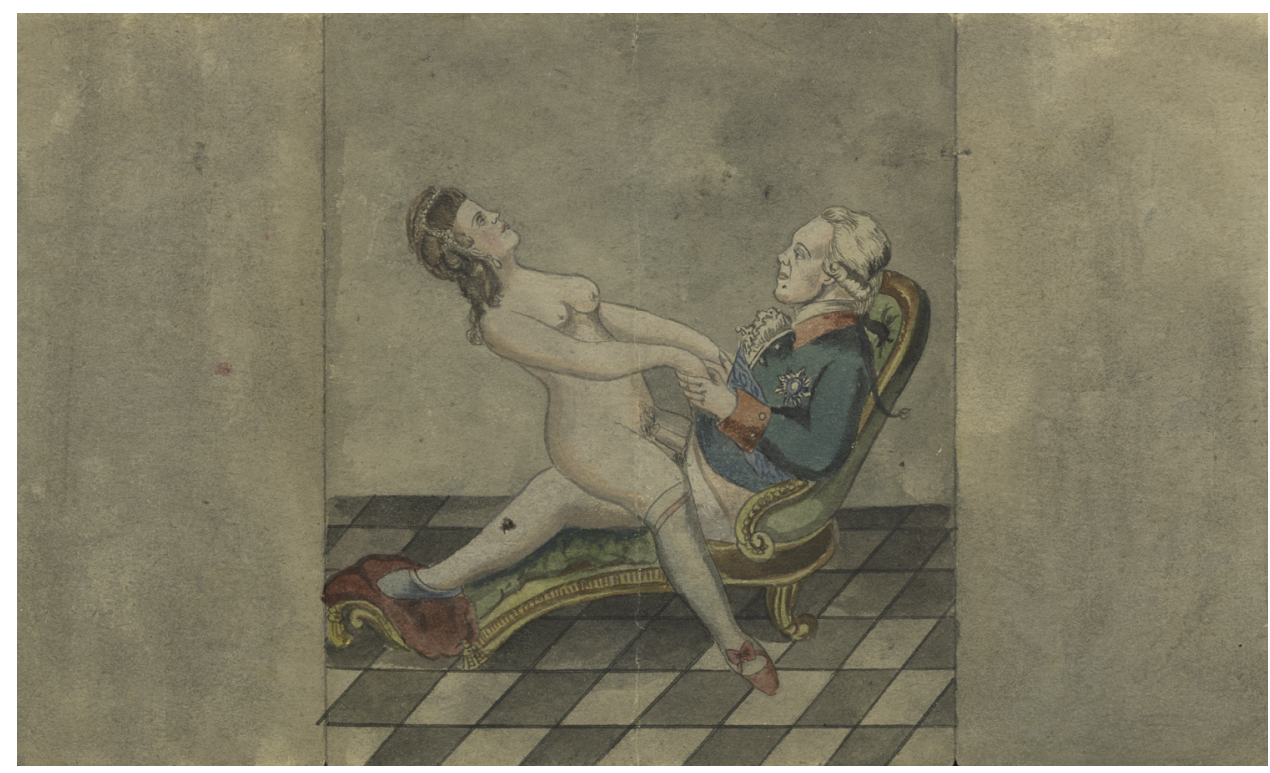

Plate 5 Russian, Anonymous. [Emperor Paul I and Sophie Dorothea of Württemberg (Empress Maria Fedorovna)]. "Folded" or "double picture." First half of the nineteenth century. Watercolor and iron-gall ink on unmarked, hand-pressed sheet of medium-weight, wove paper. $18 \times 29 \mathrm{~cm}$. NYPL Slav. Reserve 01-1316. Courtesy New York Public Library.

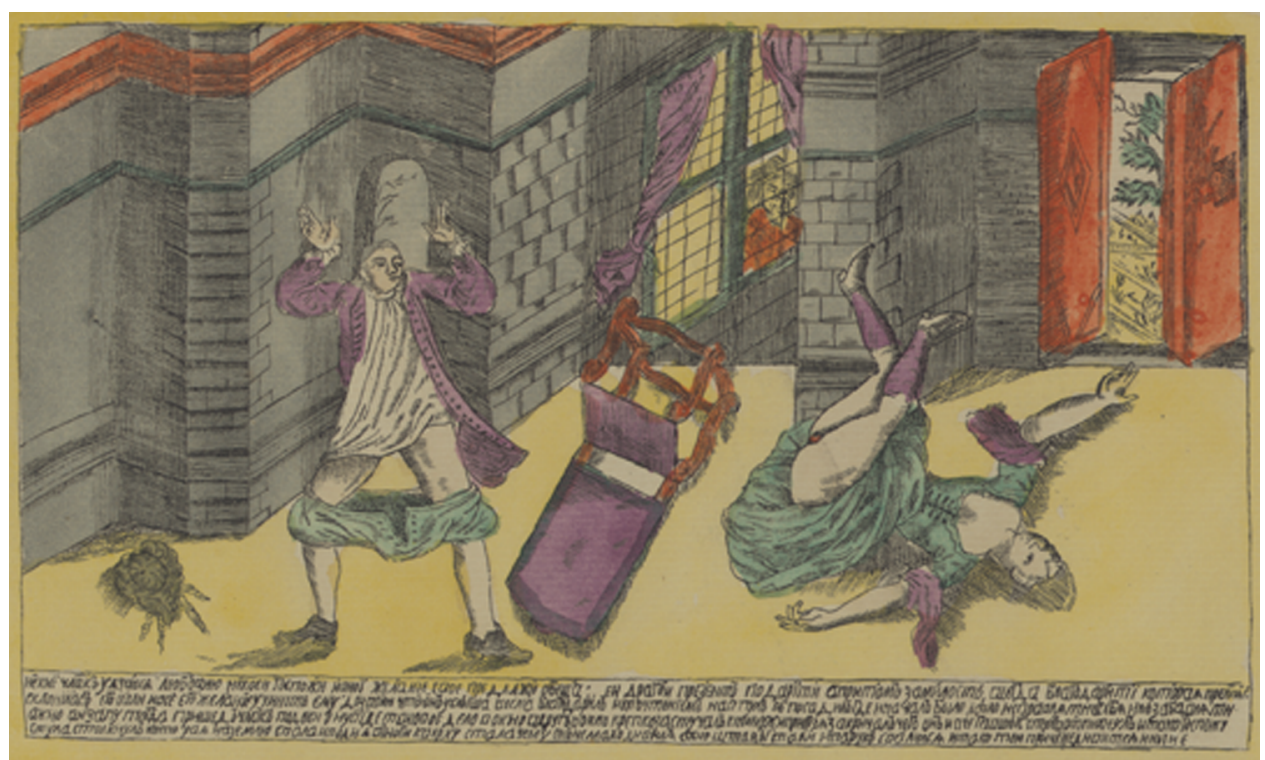

Plate 6 [P. N. Chuvaev]. "Pomekha v liubvi." Hand-colored print. Late eighteenth century. From D. A. Rovinskii, Russkiia narodnyia kartinki, 5 vols. (St. Petersburg, 1881). Image ID: 1162472. Courtesy New York Public Library. 


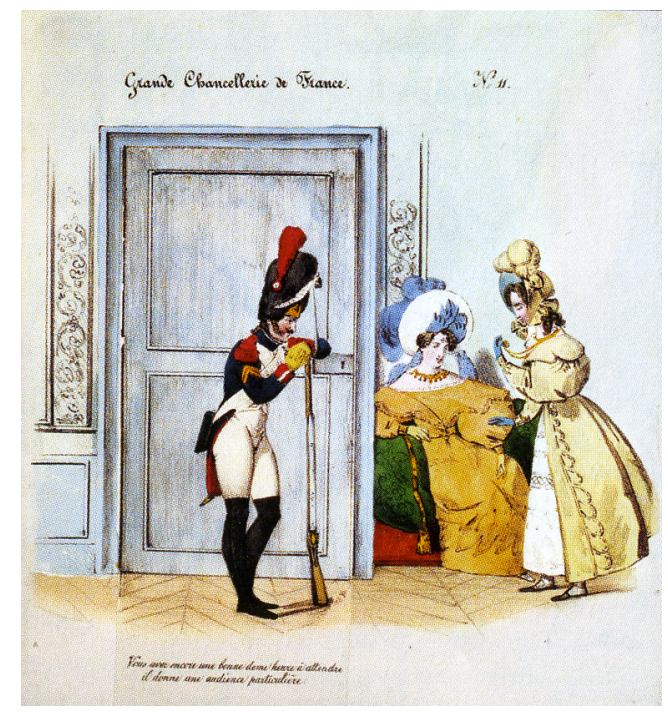

Plate 7 [Pierre Numa-Bassaget]. "No. 11: La Grande Chancellerie du France [exterior]." From Portes et fenêtres: Collection de 36 dessins coloriés à la main et lacqués (Paris, [c. 1835]). Reprinted from Indescrétions: 36 planches érotiques [= L'iconothèque, vol. 10] ([Paris], 1990). Courtesy of Harenberg Kommunikation Verlags- und Medien-GmbH u.Co.KG.

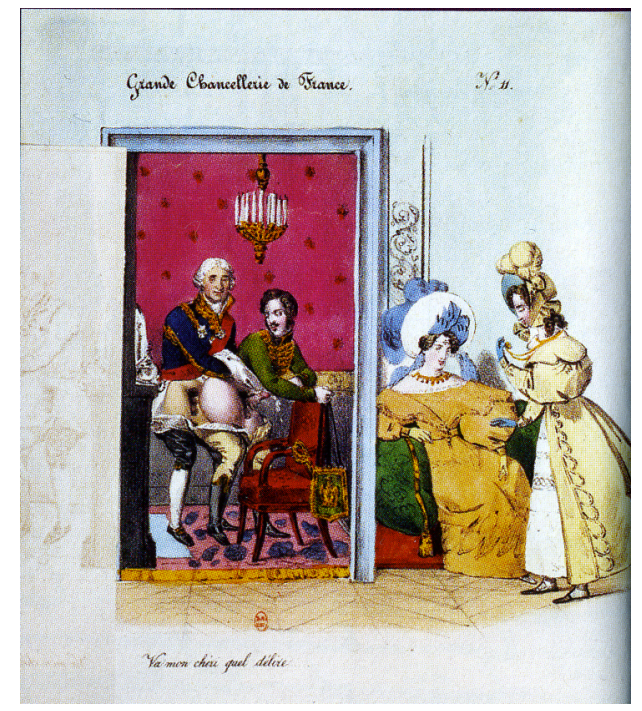

Plate 8 [Pierre Numa-Bassaget]. "No. 11: La Grande Chancellerie du France [interior]." From Portes et fenêtres: Collection de 36 dessins coloriés à la main et lacqués (Paris, [c. 1835]). Reprinted from Indescrétions: 36 planches érotiques [= L'iconothèque, vol. 10] ([Paris], 1990). Courtesy of Harenberg Kommunikation Verlags- und Medien-GmbH u.Co.KG. 


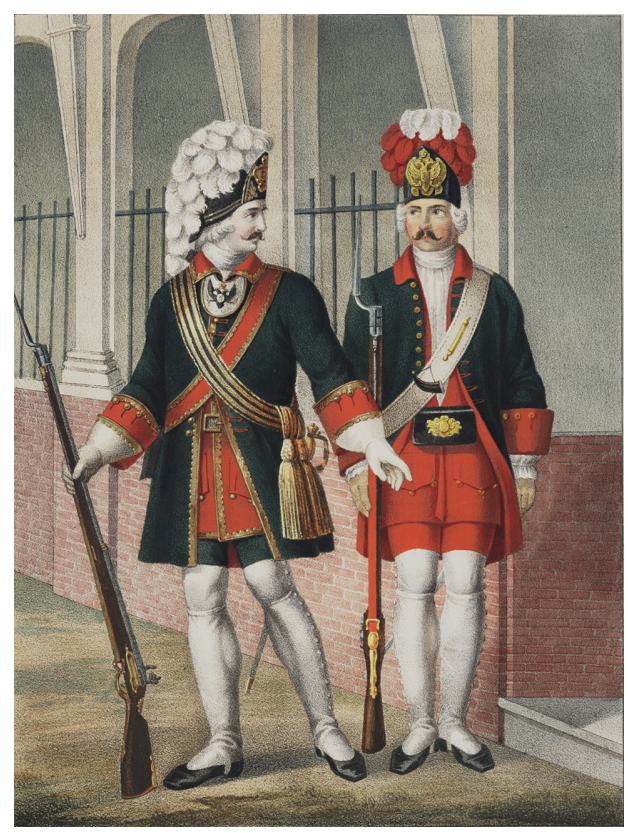

Plate 9 [Designed by B. A. Chorikov and N. N. Kolpashnikov; lithographed by I. P. Fridrits]. "Grenaderskii ofitser i riadovoi grenader Leib-Gvardii Preobrazhenskogo polka s 1732-1742 god." Hand-colored lithograph, 1841. From Risunki k istoricheskomu opisaniiu odezhdy $i$ vooruzheniia rossiiskikh voisk s IX v. do 1855 (St. Petersburg, 1840-62), 2:276. Courtesy Library of Congress.

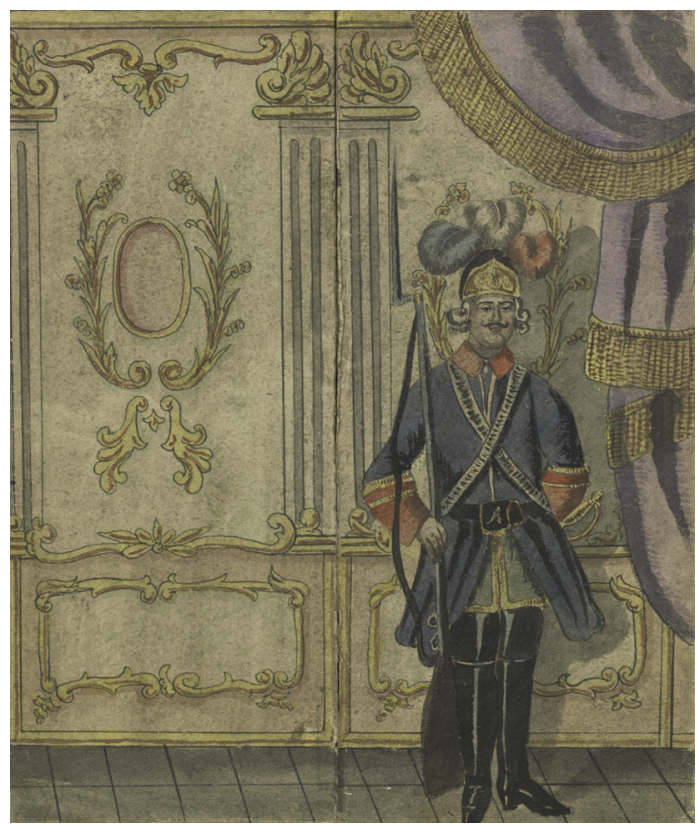

Plate 10 Russian, Anonymous. [Sentry from the reign of Empress Anna Ioannovna]. Exterior of "folded" or "double picture." First half of the nineteenth century. Watercolor and iron-gall ink on unmarked, hand-pressed sheet of medium-weight, wove paper. 18 x $29 \mathrm{~cm}$. NYPL Slav. Reserve 01-1316. Courtesy New York Public Library. 


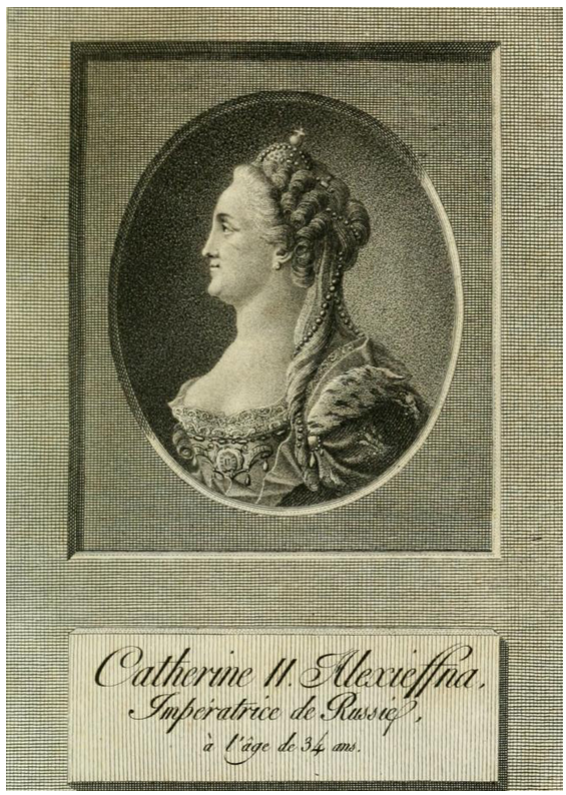

Plate 11 "Portrait de Catherine II. Alexieffna, Impératrice de Russie, à l'age de 34 ans." From Jean-Henri Castéra, Histoire de Catherine II, impératrice de Russie, 3 vols. (Paris, 1800), 1:288.

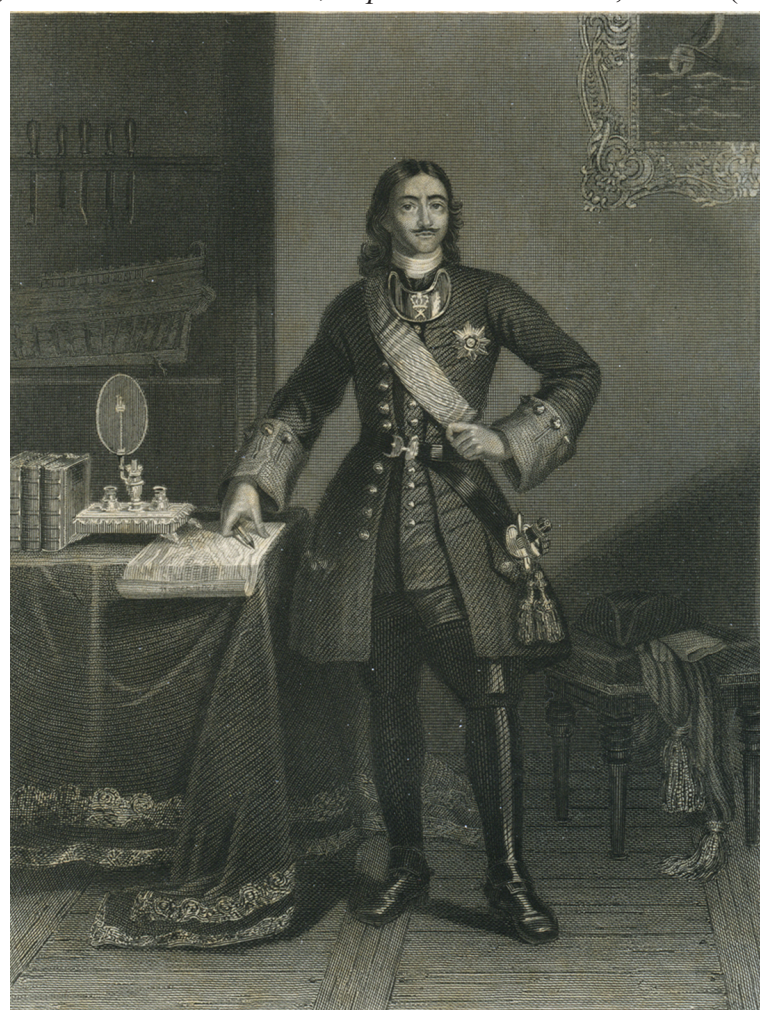

Plate 12 H. Robinson after Nicolas-Sébastien Frosté. Portrait of Emperor Peter I. Copper-plate engraving. Utrenniaia zaria: Al'manakh na 1841 god (St. Petersburg, 1841), between pp. 2 and 3. 
Plate 4 [Catherine II and Potemkin]

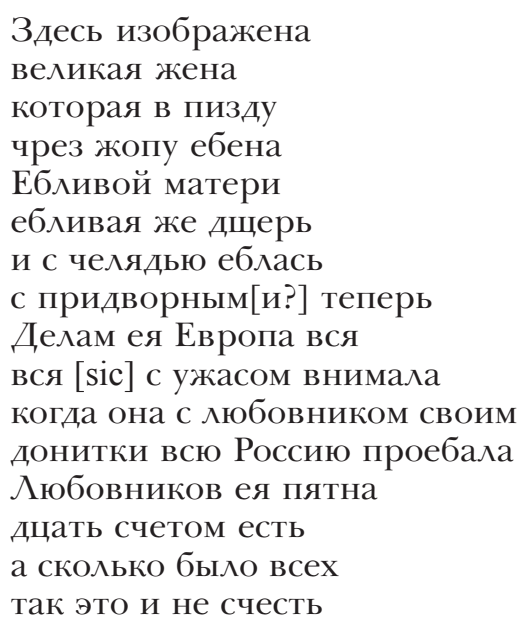

\author{
Here is depicted \\ a great woman/wife \\ being fucked \\ in the cunt through her ass. \\ The fucked-up daughter \\ of a fucked-up mother, \\ she screwed around with her menials, \\ now called courtiers. \\ All of Europe looked \\ with horror upon her deeds \\ as she and her lover \\ fucked all of Russia to shreds. \\ By one count \\ she supposedly had fifteen lovers, \\ but it is impossible to count \\ how many there actually were.
}

The striking similarity between these grossly indecent inscriptions and the obscene epitaphs composed by Ivan Barkov suggests that the anonymous authors and illustrators of the NYPL series were intimately familiar with the oeuvre of the legendary founder of Russian literary pornography and could easily adapt it for their own purposes. ${ }^{11}$ And in this case, the purpose was clearly to "eulogize" some of Russia's most famous monarchs using the lewd language and sexual frankness found in the manuscript miscellanies of Barkoviana, which circulated privately among members of the Imperial Russian elite from the late eighteenth century onward. ${ }^{12}$

The curators of the 2003 NYPL exhibition used this "bit of bawdy verse in a late eighteenth-century hand" to date the series to the 1790s. ${ }^{13}$ According to the published catalogue entry, this dating also relied on "the accuracy of the guard's uniform (particularly its coloration) and of the representations of the royal couples," a level of detail that "suggests that these drawings were prepared by someone with knowledge of, and perhaps entree to, court circles." ${ }^{14}$ In addition, it also seems likely that the fifth and last watercolor in the

\footnotetext{
${ }^{11}$ The opening lines of the epigram on Catherine the Great, for example, appear to have been inspired by Barkov's "Epitaph to a Procuress," which was itself a translation of an epigram called "Tombeau d'une vielle Courtisanne," from a seventeenth-century collection of erotic French verse called Cabinet Satyrique. See I. S. Barkov, "Epitafiia 6-ia (Svodne)," in Devich'ia igrushka, ili Sochinenie gospodina Barkova, ed. A. Zorin and N. Sapov (Moscow, 1992), 212, 393; Barkov, "Nadgrobnaia k zhenshchine," in his Polnoe sobranie stikhotvorenii (PSS), ed. Valerii Sazhin (St. Petersburg, 2004), 486 (no. 227), 590-91; and Andrei Dobritsyn, Vechnyi zhanr: Zapadnoevropeiskie istoki russkoi epigrammy XVIII-nachala XIX veka (Bern, 2008), 140.

${ }^{12}$ Scholarly editions of Barkoviana were not published until the end of the twentieth century. See Zorin and Sapov, Devich'ia igrushka; N. Sapov, ed., Pod imenem Barkova: Eroticheskaia poeziia XVIII-nachala XIX veka (Moscow, 1994); A. Ranchin and N. Sapov, eds., Stikhi ne dlia dam: Russkaia netsenzurnaia poeziia vtoroi poloviny XIX veka (Moscow, 1994); and Aleksei Plutser-Sarno, "Russkaia pornograficheskaia literatura XVIII-XIX vv. (Razmyshleniia nad knigami serii 'Russkaia potaennaia literatura')," Novoe literaturnoe obozrenie 28 (2001): 358-86.

${ }^{13}$ Russia Engages the World, 192. The curators for this section of the exhibit were Robert H. Davis, Jr. and Cynthia H. Whittaker. See also http://catalog.nypl.org/record=b14991475 S38, where the series is dated [1790-99?].

${ }^{14}$ Russia Engages the World, 180.
} 
series, depicting Catherine's hapless, if still-very-much-alive son (d. 1801), provided the NYPL curators' with a terminus ante quem. Nevertheless, their tentative dating suggests that the exhibit organizers were aware of the circumstantial nature of these arguments about the late-eighteenth-century provenance of the NYPL watercolors. For even if the hand in which these obscene epigrams were written did belong to the late eighteenth century, this does not mean that the set of watercolors itself dates to that period. After all, it is not inconceivable that the anonymous authors of these verses could have been taught penmanship in the eighteenth century, but lived to use it in the nineteenth. It is also possible that they may have deliberately tried to imitate the archaic handwriting and style of an earlier period. Even the assumption that the paper was produced at the turn of the eighteenth-century does not necessarily imply that this is the period in which the drawings were actually executed, since Russian wove paper remained in circulation long after the advent of mechanized paper mills, in the first third of the nineteenth century. ${ }^{15}$

The fact that these "manuscript annotations range in handwriting style," however, does confirm that the NYPL series was the product of a collective, rather than an individual act of creation. ${ }^{16}$ Similarly, the fact that the authors of these obscene "annotations" frequently could not fit their verses into a single line of poetry also suggests that the inscriptions accompanying each sexually explicit royal portrait were added after the execution of the central pen-ink drawing and the application of watercolors - and, most likely, in response to it. This means that the NYPL series was actually composed in several stages, the last one being the use of a glue pot and brush to paste each item (on the back, at each of the four corners) onto successive pages of some kind of private scrapbook or album. Because these watercolors were ripped from the pages to which they were originally attached, we will probably never know what else was included between the covers of this no-longer-extant album. However, we can be fairly certain that it would not have been typical sentimental and moralistic expressions of friendship and affection. Although the "dialogic" and "ludic" nature of the milieu in which this particular album was produced would have been similar to that of other artifacts of Russian salon culture, the content revealed by turning its pages was radically different from the poetry, charades, and playful ruses usually found in late eighteenth- and early nineteenth-century examples of the genre. As with other albums, the medium's nonlinear, interactive format would have encouraged both owner and spectator to participate in its reading and interpretation, a process that, in this case, required filling in some missing pieces of information (anecdotes about the "secret history" of the Romanov dynasty) and performing a physical action (lifting a paper device made to look like a door to the royal boudoir). ${ }^{17}$

${ }^{15} \mathrm{Z}$. V. Uchastkina, A History of Russian Hand Paper-Mills and Their Water-Marks (Hilversum, The Netherlands, 1962), 57.

${ }^{16}$ NYPL Slav. Reserve 01-1316.

${ }^{17}$ Justyna Anna Beinek, "The Album in the Age of Russian and Polish Romanticism: Memory, Nation, Authorship" (Ph.D. diss, Harvard University, 2001), 23, 32-33, 137, 140; A. V. Kornilova, Mir al'bomnogo risunka: Russkaia al'bomnaia grafika XVIII-pervoi poloviny XIX veka (Leningrad, 1990). On Russian historical anecdotes see Simon Dixon, "The Posthumous Reputation of Catherine II in Russia, 1797-1837," Slavonic and East European Review 77 (October 1999): 655-56; E. K. Nikanorova, Istoricheskii anekdot v russkoi literature XVIII veka: Anekdoty o Petre Velikom (Novosibirsk, 2001); and, more generally, E. Kurganov and N. Okhotin, eds., Russkii literaturnyi anekdot kontsa XVIII-nachala XIX veka (Moscow, 2003). 
Very few Russian albums with sexually explicit imagery have survived, and fewer still have been analyzed for their content. ${ }^{18}$ In fact, there is only one well-documented example of an album of erotic drawings and engravings: that of the famous Polish-born, Russian graphic artist Aleksandr Orlovskii. Although this artistic virtuoso is best known for his renderings of Romantic genre scenes, Russian military uniforms, and charged personal caricatures, he was also renowned for an infamous album of "unseemly" and "explicit" drawings and engravings, which he shared among a close circle of male friends. ${ }^{19}$ We know of the existence of this album primarily because one of Orlovskii's acquaintances happened to be Alexander Pushkin, Russia's national poet, who was himself on occasion known to sketch erotic drawings in the margins of the notebooks containing rough drafts of his works. ${ }^{20}$ Needless to say, private, illustrated albums such as Orlovskii's reflected the personal tastes of their owner and viewers and so cannot be assumed to have belonged only to those individuals with a particular political agenda. The same goes for the contents of these albums, such as the series of erotic watercolors under discussion. In fact, our only guide to the possible meaning that these "double pictures" held for their creators is the anonymous and undated set of watercolor drawings itself. This is precisely what makes it so challenging to work with, and what justifies, if there needs to be any additional justification, devoting scholarly attention to this unique artifact of Russian material and visual culture. Far from diminishing the historical importance of the NYPL series, its very anonymity and uniqueness make it a valuable primary source for an inquiry into the nature of the cultural processes that produce the notion of Russian "political pornography."

\section{INVERSION}

Even a cursory glance at the NYPL series reveals its debt to the visual vocabulary of eighteenth-century Russian popular prints $(l u b k i) .{ }^{21}$ By the turn of the nineteenth century

\footnotetext{
${ }^{18}$ For examples of such drawings see the reproduction of two anonymous, sexually explicit watercolors on paper from an early nineteenth-century Russian album in Marina Dzhigarkhanian, comp., Palomnichestvo na ostrov Kiferu: Liubov' i erotika v izobrazitel'nom iskusstve: Mezhdunarodnaia vystavka (St. Petersburg, 1997), 72-73; and Karl Bryullov, "Silenus, Satyr, and Bacchae," in Drawing and Watercolours in Russia: The Eighteenth Century, ed. Yevgenia Gavrilova et al. (St. Petersburg, 2005), 107 (no. 161, a sepia and graphite pencil sketch from an album dating to the first half of the 1830s).

${ }^{19}$ I. I. Svirida, "Aleksandr Orlovskii," in Mezhdu Peterburgom, Varshavoi i Vil'no: Khudozhnik v kul'turnom prostranstve: XVIII-seredina XIX vv.: Ocherki (Moscow, 1999), 161. See also V. A. Vereshchagin, Russkaia karikatura, 3 vols. (St. Petersburg, 1911-13), vol. 3 (A. O. Orlovskii): 73-74 (nos. 101, 107), 34, 37-38, 54; D. A. Rovinskii, Podrobnyi slovar' russkikh graverov XVI-XIX vv., 2 vols. (St. Petersburg, 1895), 2:725 (nos. 11-12). The preceding two sources both refer to Julian Kołaczkowski, Stownik rytowników polskich tudziez obcych $w$ Polsce zamieszkatych lub czasowo $w$ niej przebywajaçych, od najdawniejszych do najnowszych czasów, jako przyczynek do historji sztuk piknych w Polsce (Lvov, 1874), 43-46.

${ }^{20}$ On Pushkin's erotic drawings see Denisenko, Eroticheskie risunki Pushkina, 23; and idem, "Kommentarii," in A. S. Pushkin, Polnoe sobranie sochinenii v 17 [sic] tomakh, 19 vols. (Moscow, 1994-96), 18:541-82, esp. 561-66.

${ }^{21}$ For a general discussion of the influence of Russian popular prints on nineteenth-century Russian visual satire see G. G. Pospelov and G. Iu. Sternin, "Izobrazitel'noe iskusstvo," in Ocherki russkoi kul'tury XIX veka: Khudozhestvennaia kul'tura (Moscow, 2002), 104-6, 167. On the erotic in Russian popular prints see Alec Flegon, Eroticism in Russian Art (London, 1976), 39, 50-51, 55; and Diane E. Farrell, "The Bawdy Lubok: Sexual and Scatological Content in Eighteenth-Century Russian Popular Prints," and N. L. Pushkareva, "Russkie
} 
these crude, wood-block or etched-metal engravings had become a key source of "folksy" imagery for Russian graphic artists, such as the ones affiliated with Syn otechestva, the patriotic journal that published a series of anti-Napoleonic caricatures on behalf of the Russian government, which briefly lifted the prohibition on caricatures of high-standing figures (as long as they were charged portraits of the enemy). ${ }^{22}$ The makers of traditional Russian prints were less overtly political, more attuned to the demands of the domestic mass market, and, consequently, more inclined to depict the public staging of carnivalesque "anti-behavior," that is, the kind of license usually associated with seasonal holidays, street fairs, and popular side-show characters. ${ }^{23}$ But they were at least as xenophobic as their elite counterparts. Despite the fact that native print-makers frequently relied on originals produced abroad, foreigners and their Russian cousins, the "Frenchified" fops, appeared in lubki as the very epitome of vice. Most important for our purposes, these stock characters were usually shown engaging in risqué, sexualized behavior, as they do, for example, in a popular print called "An Impediment to Love" by the prolific, late eighteenth-century, Moscow-based engraver P. N. Chuvaev (plate 6). ${ }^{24}$

Judging by the fact that "An Impediment to Love" was published in at least two different versions, Chuvaev's most explicit print was also one of his most popular. There is also reason to believe that this popular engraving may have inspired the nineteenth-century amateur draftsman who created the first erotic watercolor in the NYPL series, depicting Peter the Great and his wife in an act that, in the original version, was interrupted (to comic effect) by a rap on the window. A comparison of the themes and techniques employed by Chuvaev and the anonymous creator of the watercolor drawing reveals a striking similarity of color, staging, and domestic interiors, right down to specific details, such as the discarded wig/tircorn hat and the prominently placed window, which, in the engraving, is occupied by a peeping Tom who effectively models the voyeuristic relationship between the print's characters and its audience. All of these details invite the viewers of the erotic watercolor to see Peter the Great, the "modernizing" monarch who "opened a window to Europe" and founded the Imperial navy (hence his attribute, the ship on the shelf above him) as a comical and bawdy character on the stage of the popular theater. In fact, not just as any character,

lubochnye kartinki XVIII-XX vv.: Nachalo pornografii ili otrazhenie eroticheskikh vozzrenii?" both in Eros and Pornography in Russian Culture, 16-41 and 42-53, respectively.

${ }^{22}$ See Karikatury Napoleona I (1813-1815?), NYPL Digital Gallery, available at http://digitalgallery.nypl.org/ nypldigital/dgkeysearchresult.cfm?parent_id=592587\&word= (last accessed March 5, 2008). Analyzed in M. Peltzer, "Imagerie populaire et caricature: la graphique politique antinapoléonienne en Russie et ses antécédents pétroviens," Journal of the Warburg and Courtauld Institute 48 (1985): 189-221; Stephen M. Norris, A War of Images: Russian Popular Prints, Wartime Culture, and National Identity, 1812-1945 (DeKalb, IL, 2006), 335; and E. A. Vishlenkova, "Uvidet' geroia: Sozdanie obraza russkogo naroda v karikaturakh 1812-go goda," in Dekabristy: Aktual'nye problemy i novye podkhody, ed. O. I. Kiianskaia (Moscow, 2008), 136-52, esp. 136-37, 141, 143-44, and 149.

${ }^{23}$ Blinshchitsa, ID: 1162457, NYPL Digital Gallery, available at http://digitalgallery.nypl.org/nypldigital/ id?1162457; and Karlik $i$ karlitsa, ID: 1162550, ibid., available at http://digitalgallery.nypl.org/nypldigital/ id?1162550 (both last accessed March 5, 2008). See also, at the same online digital gallery, Reestr o tsvetakh i mushkakh, ID: 1162548; Semik i Maslianitsa, ID: 1162438; and Eshche Maslianitsa i Semik, ID: 1162439. For a definition of "anti-behavior" see B. A. Uspenskii, "Antipovedenie v kul'ture drevreni Rusi," in Izbrannye trudy, 2nd rev. ed., 3 vols. (Moscow, 1996-97), 1:460-76.

${ }^{24}$ Pomekha v liubvi. ID: 1162471, and Pomekha v liubvi, ID 1162472, both available at the NYPL Digital Gallery, http://digitalgallery.nypl.org/nypldigital/id?1162471 [and 1162472] (last accessed March 5, 2008). 
but as Petrushka, the chief protagonist in carnival puppet-theater, whose cudgel is as violent as it is indiscriminate in its targets. ${ }^{25}$ In this case, of course, it is the royal phallus itself that is Petrushka's stick (palka) - the word used in the coarse Russian expression for copulation (as in "sticking it to someone," palku stavit'), and employed to great effect in Pushkin's sexualized characterization of the "great Northern giant" (Peter I) who introduced enlightenment, but kept everyone equally in thrall to his "little cudgel" (dubinka) or "stick" (palka). ${ }^{26}$ This double-entendre also informs the obscene epigram accompanying the watercolor, in which Great Peter's wide-ranging sexual activity is said to have quite literally made him "Father of the Fatherland"- a suggestion reminiscent of Barkov's obscenityladen ode "To a Cock" ("Khuiu"), the "all-powerful hero ... regenerator of all creatures ... the founder and father of all." ${ }^{27}$ This self-conscious attempt to deflate Imperial pomposity sets the tone for the rest of the royal portraits in the NYPL series, each of which is accompanied by an explanatory text full of salty market language, depicts a scene of debauchery and carnivalesque role-reversal, and deliberately figures the debasement of Russian monarchs to the level of lubok characters and situations.

\section{PERVERSION}

Despite their obvious connection to the carnivalesque xenophobia of the Russian popular print, however, the NYPL watercolors are even more heavily indebted to elite, foreign sources, and particularly to European erotic visual culture, which had its own moralistic tradition of linking sexual and political perversity. Indeed, the series' attention to sexual choreography inevitably brings up the question of the degree to which its creators were familiar with the infamous illustrations to I modi, Pietro Aretino's series of sonnets on the joys of various coital positions. Aretino's work was first published in 1525, in Rome, in an edition that included the etchings of Marcantonio Raimondi, made from a series of sixteen drawings by Giulio Romano, a student of Raphael. Although, this publication was instantly banned by the Catholic Church and burned by the Inquisition, a couple of cheap knock-offs survived past the sixteenth century. ${ }^{28}$ Despite the fact that it was undoubtedly a very rare commodity, there is evidence that Aretino's work was known in Russia. Indeed, judging by the sexually explicit suite of frescos that once decorated the walls of the royal palace in Gatchina, "Aretino's postures" were part of the visual vocabulary of the Russian imperial elite from at least the second half of the eighteenth century. ${ }^{29}$ By the beginning of the nineteenth century, however, Aretino's name had become associated with a whole new

\footnotetext{
${ }^{25}$ Catriona Kelly, "A Stick With Two Ends or Misogyny in Popular Culture: A Case Study of the Puppet Text 'Petrushka,"' in Sexuality and the Body in Russian Culture, ed. Jane T. Costlow et al. (Stanford, 1993), 73-96; and Kelly, Petrushka: The Russian Carnival Puppet Theatre (Cambridge, England, 1990).

${ }^{26}$ A. S. Pushkin, "[Zametki po russkoi istorii XVIII veka (1822)]," in his Polnoe sobranie sochinenii v 16 tomakh (Moscow, 1937-59), 11:14-17, 288-89.

${ }^{27}$ Barkov, "Oda 5-ai: Khuiu," PSS, 304-6.

${ }^{28}$ Lynne Lawner, I modi: The Sixteen Pleasures: An Erotic Album of the Italian Renaissance: Guilio Romano, Marcantonio Raimondi, Pietro Aretino, and Count Jean-Frederic-Maximilien de Waldeck (Evanston, IL, 1988); and Bette Talvacchia, Taking Positions: On the Erotic in Renaissance Culture (Princeton, 1999).

${ }^{29}$ On the Gatchina frescos see Flegon, Eroticism in Russian Art, 85, 61, 64-65, 68; and Bernard Gip, Les passions de la grande Catherine (Paris, 1970). I owe the latter reference to Simon Dixon.
} 
genre of "writings about prostitutes," called "pornography," and could no longer be pronounced in mixed company. ${ }^{30}$ Unless, of course, that company actually included prostitutes, as it did, for example, in an 1823 letter that Pushkin addressed to some unidentified female inhabitants of the Kishinev demimonde, whom he personally promised to sketch, presumably from nature and au naturel, "in the 38 [sic] positions of Aretino"an inflated figure that appears to have derived from the rare, sixteenth-century copy of Aretino's Dialogues, which Pushkin found in the Odessa library of his friend and fellow litterateur, Prince P. A. Viazemskii. ${ }^{31}$

Although there is no evidence that Pushkin ever executed the promised sketches $\grave{a}$ l'Arétin, we do know that his doodles were frequently based on eighteenth-century French book illustrations and that such publications were one of the most accessible sources of the poet's graphic and literary images. ${ }^{32}$ Like Pushkin, the creators of the NYPL series also appear to have been indebted to the numerous illustrated, erotic publications that were imported clandestinely to Russia, particularly from France, the home of both liberty and libertinism. On the surface, the Russian watercolors even appear to be styled after the engravings of revolutionary, antimonarchist pamphlets, particularly those directed against the "uterine fury" of Marie-Antoinette, wife of King Louis XVI. ${ }^{33}$ However, compared to the libelles' graphic violence, the Russian drawings seem less intent on bringing down the Imperial double-headed eagle than in covertly flipping the bird (mano fica) to the powersthat-be. ${ }^{34}$ This may be as much a result of the different formats in which these images were presented to their respective audiences as of the social composition of the audiences themselves. For unlike the crudely etched, mass-produced examples of printed "political pornography" analyzed by Hunt and other scholars of the French Revolution, the handdrawn Russian watercolors appear to have been intended for and circulated among a much smaller, more refined, elite group - one that could not only appreciate the drawings' inherent intertextuality, but that was also forced by political circumstances to whisper, not declaim. ${ }^{35}$

${ }^{30}$ Walter M. Kendrick, The Secret Museum: Pornography in Modern Culture (New York, 1987); Lynn Hunt, "Introduction," in The Invention of Pornography, 9-45, esp. 13-14.

${ }^{31}$ A. S. Pushkin, Pis'ma, 1815-1825, ed. B. L. Modzalevskii (Moscow, 1926), 1:63 (no. 67); N. O. Lerner, "Pushkinologicheskie etiudy, VIII: Pushkin i Aretino," Zven'ia 5 (1935), 122-25; M. N. Rozanov, "Pushkin, Tasso, Aretino," Izvestiia AN SSSR. Otdelenie obshchestvennykh nauk 2-3 (1937): 369-74; and Aleksandr Sevast'ianov, "Legendarnyi ozornik: K 500-letiiu P'etro Aretino," Knizhnoe obozrenie 11 (1995): 30, 12 (1995): 14, and 13 (1995): 10.

${ }^{32}$ Denisenko, "Kommentarii," 561-66.

${ }^{33}$ Fureurs utérines de Marie-Antoinette, femme de Louis XVI (Paris, 1791). The frontispiece of this libelous, antimonarchist brochure is reproduced in color in Marie-Françoise Quignard and Raymond-Josué Seckel, eds., L'enfer de la Bibliothèque: Eros au secret (Paris, 2007), 133, ill. 36 (cat. 77). See also Hunt, "Pornography and the French Revolution"; idem, "The Political Psychology of Revolutionary Caricatures," in French Caricature and the French Revolution, 1789-1799, ed. James Cuno (Los Angeles, 1988), 33-40, esp. 37 (fig. 1); Chantal Thomas, La reine scélérate: Marie-Antoinette dans les pamphlets (Paris, 1989).

${ }^{34}$ I owe this observation to Henryk Baran. The expression "Holding a fig in one's pocket" (derzhat' kukish or figu v karmane) is the Russian version of the "fig hand" (mano fica), an obscene or apotropaic hand gesture in which the thumb is thrust between the curled index and middle fingers in obvious imitation of heterosexual intercourse.

${ }^{35} \mathrm{Cf}$. Iurii M. Lotman's comments about the difference between "a written printed text" and "a handwritten one," which he likens to "the difference between public speaking and whispering" (Universe of the Mind: A Semiotic Theory of Culture [London, 2001], 64). 
In fact, the most proximate foreign sources for the NYPL watercolors are not illustrated libelles, but rather gravures galantes, which were popular in Paris during the early years of the so-called July Monarchy (1830-48), the brief experiment in constitutional monarchy that followed the violent overthrow of the Bourbon dynasty and the election of Louis Phillipe as "King of the French." 36 Particularly influential in this regard was the sexually explicit series of lithographs created around 1835 by Pierre Numa Bassaget, "a prodigious illustrator of erotic scenes" and occasional contributor to La Caricature, one of the most famous satirical journals of the nineteenth century, which was published by Charles Philipon, the French entrepreneur who "encouraged and facilitated the development of modern political caricature." ${ }^{\prime 37}$ Numa's series of thirty-six hand-colored lithographs was called Doors and Windows (Portes et fenêtres) and, as its name suggests, it depicted a decorous outside and a "piquant" inside, which was revealed whenever the viewer lifted a piece of paper decorated to look like a door or window-a "surprise" that often provided an extension of, or commentary on, the caption written beneath the original image (plates 7-8). ${ }^{38}$ Like all the other works put out by Phillipon's La Maison Aubert, this series of erotic prints was a projection of the fantasies not only of the publisher and his artist, but also of their reading public. For the same liberal-minded, middle-class gentlemen who leered at Numa's titillating lithographs also laughed at La Caricature's political satire. In fact, these two popular genres (erotica and caricature) were both part of the same print market - a market opened up by the events of the Revolution of 1830 , which resulted in the sudden elimination, however short-lived, of government censorship of the press. ${ }^{39}$

Needless to say, things were very different in contemporary Russia. Indeed, the political reaction that set in after December 1825, as a direct result of the unsuccessful attempt on the part of a group of elite military officers to overthrow the Russian monarchy and replace it with a republican form of government, was only strengthened by the 1830 Revolution. Especially since events in France reverberated not only in Europe but also closer to home, in Russian-controlled Poland, which experienced the so-called Cadet Revolution or November Uprising of 1830-31. These revolutionary upheavals guaranteed that there would not be an open market in either caricatures or erotica (and much else besides) during the long and oppressive reign of Nicholas I (r. 1825-55). However, this did not prevent the

\footnotetext{
${ }^{36}$ For an insightful discussion of gravures galantes see Jo Burr Margadant, "Gender, Vice, and the Political Imaginary in Postrevolutionary France: Reinterpreting the Failure of the July Monarchy, 1830-1848," American Historical Review 104 (December 1999): 1461-96; and Abigail Solomon-Godeau, "The Other Side of Venus: The Visual Economy of Feminine Display," in The Sex of Things: Gender and Consumption in Historical Perspective, ed. Victoria de Grazia, with Ellen Furlough (Berkeley, 1996), 113-50.

${ }^{37}$ On Numa, and his gravures galantes, see Albert Boime, Art in an Age of Counterrevolution, 1815-1848 (Chicago, 2004), 398; and Henri Béraldi, Les graveurs du XIXe siècle: Guide de l'amateur d'estampes modernes, 12 vols. (Paris, 1885-92), 10:223-31. On Phillipon see James Cuno, "Charles Philipon, La Maison Aubert, and the Business of Caricature in Paris, 1829-41," Art Journal 43 (Winter 1983): 347-48; idem, "Charles Phillipon and La Maison Aubert: The Business, Politics, and Public of Caricature in Paris, 1820-1840" (Ph.D. diss., Harvard University, 1985), 91, 76-79, 78 n.32; and David S. Kerr, Caricature and French Political Culture, 1830-1848: Charles Phillipon and the Illustrated Press (New York, 2000), 61 n.141.

${ }^{38}$ Portes et fenêtres: Collection de 36 dessins coloriés à la main et lacqués (Paris, [c. 1835]), reproduced in L'enfer de la Bibliothèque, 234, nos. 144-46 (ill. 66 and 67); and Indescrétions: 36 planches érotiques ([Paris], 1990). I owe the latter reference to Irina Tarsis.

${ }^{39}$ Cuno, Charles Phillipon, 82, 86.
} 
actions of interested individuals and the operations of black-marketers, who managed to circumvent the restrictions placed by the government, which censored all foreign publications imported into Russia. ${ }^{40}$ Judging by the similarity, for instance, between the anonymous draftsman's image of the illicit coupling of Empress Anna and Biron (plate 2) and Numa's depiction of the furtive homosexual encounter taking place in the "Grande Chancellerie du France" (plate 8), it appears that the creators of the Russian erotic watercolors did indeed have access to the famous French satirical publication. Even if they were not actual subscribers to La Caricature, they were obviously very familiar with, and inspired by La Maison Aubert's lithographs, which were designed to be easily detachable, highly portable, and very suitable for framing or collecting in an album. ${ }^{41}$

\section{SUBVERSION}

Although the domestically produced, hand-drawn examples of obscene graphic satire under discussion do not match the venom of the antimonarchist broadsides of the French Revolution, or the "rich allusions" and "dense metaphorical implications" of Philipon's political caricatures, they cannot be dismissed merely as an innocent attempt to let off some steam. ${ }^{42}$ Their creators' use of carnivalesque inversion and foreign perversion borders too close to political subversion to be relegated to a simple case of "boys will be boys." Especially since this kind of "barracks humor" had serious and sometimes deadly political consequences for early nineteenth-century Russian elite servitors, as is clear, for example, from the infamous case of A. I. Polezhaev, a Moscow University graduate whom Nicholas I personally sent off to serve (and die) in the Caucasus merely for writing a politically offensive and sexually explicit parody of Pushkin's Evgenii Onegin..$^{43}$ The term "barracks humor" is singularly appropriate because many elite male educational institutions at the time were either directly responsible for training military servitors, or produced civil servitors on the model of their military counterparts. As in the army, students in both types of institutions were subjected to corporal punishment, wore uniforms, and were expected to obey their superiors without question, even if they frequently did not live up to such expectations. The stifling atmosphere of these totalizing institutions fostered not only nonnormative behavior (rowdiness, drunkenness) but also the production of oral, visual, and written texts (such as Polezhaev's Sashka, Puhskin's The Shade of Barkov, and Iu. M. Lermontov's "Hussar poems"). ${ }^{44}$

\footnotetext{
${ }^{40}$ Marianna T. Choldin, A Fence around the Empire: Russian Censorship of Western Ideas under the Tsars (Durham, NC, 1985); Charles A. Ruud, Fighting Words: Imperial Censorship and the Russian Press, 18041906, rev. ed. (Toronto, 2009).

${ }^{41}$ Cuno, "La Maison Aubert," 350, 352.

${ }^{42}$ Cuno, Charles Phillipon, 191.

${ }^{43}$ See Vol'naia russkaia poeziia XVIII-XIX vekov, 3rd ed. (Leningrad, 1970), 1:367-68; V. I. Bez"iazychnyi, “A. I. Polezhaev: Ocherk zhizni i tvorchestva," in Aleksandr Polezhaev: Sochineniia (Moscow, 1955), 3-54; N. F. Bel'chikov, “A. I. Polezhaev,” in A. I. Polezhaev: Stikhotvoreniia i poemy, 2nd ed. (Leningrad, 1957), 5-35. On later students' knowledge of the "history of Polezhaev" see I. D. Voronin, A. I. Polezhaev: Zhizn' $i$ tvorchestvo (Saransk, 1954), 194-95, 235-36.

${ }^{44}$ See Rebecca Friedman, Masculinity, Autocracy and the Russian University, 1804-1863 (Houndmills, 2005). See also A. S. Pushkin, Ten' Barkova: Teksty, kommentarii, ekskursy, ed. I. A. Pil'shchikov and M. I.
} 
Even before the Decembrists' uprising, Russian authorities came to regard political caricature as second only to free-thinking songs in the ease with which they could reach and mobilize a popular audience against the regime. As early as 1821 this sentiment was expressed by Adjutant-General Count A. Kh. Benkendorf, the future chief of the Third Department of His Imperial Majesty's Chancellery, the tsar's secret police force. In a memo about what could be done to prevent Russian "secret societies" from "exerting an influence on all branches of the government," Benkendorf described the methods by which their ring leaders supposedly wished to "direct public opinion and imperceptibly to prepare all estates" for subversive activities. These methods included "the spread of rumors and stories," as well as of "literary works, especially in journal article form," since these were "the easiest and quickest way to disseminate" their ideas. More important, at least for our purposes, Benkendorf singled out the revolutionary leadership's efforts to determine for their members "which books should be read and distributed, which rumors should be spread and caricatures invented, which notables should be blackened in the eyes of public opinion, how to judge the actions of the government, etc." He even alleged that two members of the St. Petersburg branch of the revolutionary leadership "considered it most opportune" to have those members who were living abroad order Parisian typographers to "print lithographs, especially caricatures," which they could then smuggle into the country, and "spread among the [common] people at the market place or send to [those serving in the] army and various provinces." $" 45$

However hyperbolic, Benkendorf's worst-case scenario, in which republican propaganda in the form of antimonarchical caricatures spread unchecked across the empire's borders, throughout its regions and up and down its social hierarchies, echoed the concerns of public officials in other countries about the particular danger of satirical drawings on political themes. In 1829, for example, the French interior minister warned his subordinates to be particularly vigilant about such drawings, because "they act immediately upon the imagination of the people, like a book ... read with the speed of light." Referring to French laws requiring prior restraint of published drawings and caricatures, he added: "It is then extremely important to forbid all which breathes a guilty intention in this regard." "46 The views of the French interior minister were shared by government officials of widely differing political regimes throughout nineteenth-century Europe, where prior censorship was required for the publication of political caricatures long after such controls were abolished for the written word. Private production and distribution of caricatures was thus part of a larger, pan-European discussion about the place of one of the oldest forms of graphic satire within modern legal definitions of what was allowed to appear and circulate in the public sphere. Not surprisingly, this discussion echoed the one taking place around "pornography," the

Shapir (Moscow, 2002); William H. Hopkins, "Lermontov's Hussar Poems," Russian Literature Tri-Quarterly 14 (1976): 36-47; and L. V. Bessmertnykh "O nekotorykh izdaniiakh eroticheskikh proizvedenii A. S. Pushkina i M. Iu. Lermontova," Novoe literatutrnoe obozrenie 6 (1993/1994): 289-305.

${ }^{45}$ [A. Kh. Benkendorf], "Zapiska Benkendorfa o tainykh obshchestvakh v Rossii [1821]," in M. Lemke, Nikolaevskie zhandarmy i literatura 1826-1855 gg., 2nd ed. (St. Petersburg, 1909), 576-77.

${ }^{46}$ Quoted in Robert Justin Goldstein, "Caricature," in Censorship, ed. R. Kent Rasmussen et al., 2 vols. (Pasadena, 1997), 1:119-20. See also Goldstein, Political Censorship of the Arts and the Press in NineteenthCentury Europe (New York, 1989). 
newly minted concept that was used to describe writings about the world's oldest profession, a term that came to acquire its modern meaning precisely around this same time.

In the case of Russia, Nicholas I's oppressively paternalistic government arrogated to itself the power to determine not only what could legally appear in print or be imported into the country, but even what was never going to appear in print at all-that is, to attempt to use the apparatus of the law (including secret police spies and informers) to monitor and regulate the private reading habits, moral proclivities, and personal behavior of its subjects. ${ }^{47}$ For in Nicholaevan Russia, as in many other authoritarian regimes, morality was equated with obedience to the powers-that-be. Indeed, the appearance in 1845 of Article 1001 of the penal code, the first piece of Russian legislation expressly directed against "obscene" and "immoral" works (what in later revisions would be called "pornography"), had as much to do with the imperial authorities' efforts to ensure political conformity among their restive subjects as with criminalizing the production and public distribution of any specific morally offensive material. This article of the penal code not only prohibited "[literary] works ... which have the goal of corrupting morals or which are obviously opposed to morality and decency," but also "corrupting images" that "tend toward" such a goal (kloniashchiesia $k$ semu soblaznitel'nye izobrazheniia). By this definition, the very act of creating a series of erotic watercolors "secretively from the censors," even in a medium that made it impossible for them to circulate beyond a small group of viewers, was a legally actionable offense. ${ }^{48}$ What made such a deed politically actionable, however, was the cartoonist's subversion of official, Russian state art and the series creators' premeditated attack on the honor of the Russian royal family itself.

Even a cursory examination of the visual sources reveals that the creators of the NYPL series both relied upon and subverted official Russian state art. First, and foremost, we must note the anonymous draftsman's debt to normative drawings from such works as $A n$ Historical Description of the Uniforms and Armaments of Russian Forces (1840-62), the first published, illustrated, multivolume description of the history of Russian Imperial uniforms. ${ }^{49}$ Unlike earlier, eighteenth-century military service manuals, which fulfilled a purely functional role and depicted contemporary uniforms solely in order to help the soldier not to make mistakes in the wearing of it, this expensive, deluxe edition sought to present the historical evolution in uniform fashions sequentially, reign by reign, over the entire period of Russian history. Each section of this historical compendium was accompanied by a separate portfolio of lithographed engravings, entitled Drawings for An Historical Description, which were specially printed and, in the case of official presentation copies, hand-colored by court artists and employees of the typographies run by the War Ministry.

\footnotetext{
${ }^{47}$ Ruud, Fighting Words; and N. A. Grichenko, "Istoriia tsenzurnykh uchrezhdenii v Rossii v pervoi polovine XIX veka," Tsenzura v Rossii: Istoriia i sovremennost': Sbornik nauchnykh trudov 1 (2001): 15-46.

${ }^{48}$ Paul W. Goldschmidt, "Article 242: Past, Present, and Future," in Eros and Pornography in Russian Culture, 459-538, esp. 460, 469, 504; idem, Pornography and Democratization: Legislating Obscenity in Post-Communist Russia (Boulder, 1999), 162-65.

${ }^{49}$ Istoricheskoe opisanie odezhdy $i$ vooruzheniia rossiiskikh voisk, sostavlennoe po Vysochaishemu povelieniiu, 30 vols. (St. Petersburg, 1840-62). For the history of this publication see G. E. Vvedenskii, Piat' vekov russkogo voennogo mundira (St. Petersburg, 2005), 315-22; and A. L. Nikitin, "K istorii sozdaniia 'Istoricheskogo opisaniia odezhdy i voorozheniia Rossiiskikh voisk," Staryi barabanshchik 1 (1995): 13-16, available at http://www.listvinoleg.nm.ru/Fon/History.htm (last accessed March 10, 2009).
} 
In fact, the first few folders of colored plates were "composed" and "etched on stone" in the very same lithography that just two years later would be charged with printing the illustrations for the new code of laws of the Russian Empire. ${ }^{50}$ The obvious similarity between the soldiers depicted in the Historical Description and those in the NYPL seriescompare, for instance, the "Officer and rank-and-file grenadier of the Preobrazhenskii LifeGuards regiment, 1732-1742" (plate 9) with the sentry guarding the door to Empress Anna's boudoir (plate 10)-lends further support to the contention that the erotic watercolors were created well after the turn of the nineteenth century, and possibly even after 1841, the publication date of the portfolio of lithographs for part two of An Historical Description, which was specifically devoted to depicting eighteenth-century Russian uniforms. ${ }^{51}$

An even more obvious example of subversion of official state art is the anonymous artist's deliberate (mis)use of official state portraits to create recognizable, and officially proscribed, personal caricatures of members of the Russian royal family. ${ }^{52}$ This intentional likeness can be seen, for example, in the depiction of Catherine II in profile, wearing an ermine and eagle-covered cape, which is clearly based on Fedor Rokotov's seated portrait of the Great Empress. ${ }^{53}$ Judging by the fact that in this watercolor Catherine appears facing right instead of left (as in the original portrait), the amateur draftsman apparently traced an engraving of Rokotov's famous painting, but did not "correct" for the mirror-image reversal built into the engraving process. In the early nineteenth century, engravings based on Rokotov's portrait could be found in numerous publications, including Jean-Henri Castéra's History of Catherine II, a popular biography to which the early nineteenth-century Russian reading public owed much of its "knowledge and understanding of the second half of the eighteenth-century" (plate 11). ${ }^{54}$ Castéra's History also included two engraved portraits of Prince Potemkin, which may have served as the model for the watercolor drawing of

${ }^{50}$ L. E. Shepelev, "Normativnye izobrazitel'nye materialy v Polnom Sobranii Zakonov Rossiiskoi Imperii," in Problemy sotsial'no-ekonomicheskoi i politicheskoi istorii Rossii XIX-XX vekov, ed. V. S. Diakin and Iu. B. Solovev (St. Petersburg, 1999), 148-49; and Irina Tarsis, "Laws and Lithographs: Seeing Imperial Russia Through Illustrations of Civil Uniforms in Polnoe sobranie zakonov Rossiiskoi Imperii," Slavic \& East European Information Resources 11 (April 2010): 156-83.

${ }^{51}$ Peremeny $v$ sostave $i$ naimenovaniiakh voisk voobshche, i izmeneniia v odezhde $i$ vooruzhenii Rossiiskikh voisk, s 1700 po 1740, pt. 2 of Istoricheskoe opisanie. Parts 3-9 covered the period up to 1801. Plates from part 2 are available in the NYPL Digital Gallery, http://digitalgallery.nypl.org/nypldigital/dgkeysearchresult. cfm?parent_id $=465059$ \&word $=$.

${ }^{52}$ For a brief discussion of the history of censorship of Russian royal portraits and the two-century ban on the publication of personal caricatures (karikatury na litsa) see Farrell, "The Bawdy Lubok," 39 n.6; John E. Bowlt, "Nineteenth-Century Russian Caricature," in Art and Culture in Nineteenth-Century Russia, ed. T. G. Stavrou (Bloomington, 1983), 230-31; and esp. D. A. Rovinskii, "Tsenzura nad tsarskimi portretami," Podrobnyi slovar' russkikh gravirovannykh portretov 4:307-12.

${ }^{53}$ F. S. Rokotov. Portrait of Catherine II (1763). Oil on canvas. $155.5 \mathrm{~cm}$ x $139 \mathrm{~cm}$. The Tretyakov Gallery, Moscow, Russia, available at http://www.tretyakovgallery.ru/ru/collection/_show/image/_id/430.

${ }^{54}$ On Castera's popularity in Russia see Dixon, "The Posthumous Reputation of Catherine II," 655-56; David M. Griffiths, "Castera-Tooke: The First Western Biographer(s) of Catherine II," Study Group on Eighteenth-Century Russia Newsletter 10 (1982): 50-62; Vladimir A. Somov, "Le livre de Castéra d'Artigues sur Catherine II et sa fortune," in Catherine II \& l'Europe, ed. Anita Davidenkoff (Paris, 1997), 211-23; and Hilde Hoogenboom, "The French Connection: Catherine the Great and Political Smut," Paper presented at the annual convention of the American Association for the Advancement of Slavic Studies, New Orleans, November 15, 2007. I am grateful to Prof. Hoogenboom for sharing her unpublished paper. 
Catherine's sexual partner. ${ }^{55}$ In fact, it appears that the original sources for most of the personal caricatures in the NYPL series were either famous eighteenth-century Russian royal portraits or their engraved reproductions. ${ }^{56}$ This is what makes the image of Russia's first emperor, the only caricature in the entire series to be modeled on a portrait of more recent historical vintage, so interesting, and what justifies the following discussion of the work of an otherwise obscure, nineteenth-century French artist named NicolasSébastien Frosté. ${ }^{57}$

Frosté, a specialist in historical portraits and religious paintings, moved to St. Petersburg in 1833, around the same time that he received a commission to paint a large portrait of Gen. A. V. Suvorov for the newly built Hall of Field Marshals in the Winter Palace. The Frenchman quickly became affiliated with Russian Academy of Fine Arts and in 1836 received the rank of naznachennyi akademik as well as official permission to teach drawing. ${ }^{58}$ Sometime before 1839, Frosté painted a full-length portrait of Peter the Great "in his study," at the very "moment when [he] is pondering the founding of Petersburg," the architectural embodiment of all his "great deeds." Contemporary critics, who recommended this work on both aesthetic and historical grounds, noted that Peter was literally surrounded by "objects taken from reality": the emperor was dressed "in the uniform of the Preobrazhensk [Guards] regiment," the very same one "that he wore during the Battle of Poltava" and that "is currently preserved in the Arsenal." To his left lay his "three-cornered hat, still not shot-through, as it would be six years later at Poltava." On the wall hung "a scene of a ship at full sail," apparently a reference to the Poltava, a man-of-war that Peter launched immediately upon his return from the 1709 battle that was the "capstone in the foundation of St. Petersburg." To his right one could see Peter's personal "shipbuilding implements," as well as a model ship that was "based on a model found in the Kunstkamera." On the table next to him was his very own "ink-well, which is still kept in the Senate; and there, as well, the map of Vasil'evskii ostrov, so reminiscent of Holland, dated 1703, the year of the founding of [St.] Petersburg." As the editors of Syn otechestva remarked, this was "much more than a mere portrait." It was a faithful reconstruction of the "majestic image" (velichestvennyi obraz, literally, "sublime icon") of

\footnotetext{
${ }^{55}$ Jean-Henri Castéra, Histoire de Catherine II, impératrice de Russie, 3 vols. (Paris, [1800]), 1:288 (portrait of Catherine at age 34), 2:192 (portrait of Potemkin at age 38), 3:1 (portrait of Potemkin at age 51), and 3:112 (portrait of Catherine at age 64); Rovinskii, Podrobnyi slovar' russkikh gravirovannykh portretov 1:641-62 (Catherine II), esp. 698-99, and 3:1807-23 (G. A. Potemkin), esp. 1809 and 1813.

${ }^{56} \mathrm{Cf}$. Castéra, Histoire, 3:175 (engraved portrait of Emperor Paul I); Louis Caravaque's official coronation portrait (1730) of Empress Anna Ioannovna (now available at http://www.tretyakovgallery.ru/ru/collection/ _show/image/_id/409\#); J.-M. Nattier's 1717 portrait of Catherine I, and Louis Tocque's 1758 portrait of Empress Elizabeth Petrovna, all of which are available online in the Hermitage Digital Collection, http:// www.hermitagemuseum.org/fcgi-bin/db2www/browse.mac/category?selLang=English.

${ }^{57}$ On Frosté see Emmanuel Bénézit, Dictionnaire critique et documentaire des peintres, sculpteurs, dessinateurs et graveurs de tous les temps et de tous les pays, rev. ed. (1913; Paris, 1999), F:103; J. Balteau, Dictionnaire de biographie française (Paris, 1933-), Fasc. 84 (1979): 1395-96; and Bruno Foucart, Le renouveau de la peinture religieuse en France, 1800-1860 (Paris, 1987), 176-77 and figs. 19-20.

${ }^{58} \mathrm{P}$. N. Petrov, Sbornik materialov dlia istorii Imperatorskoi S.-Peterburgskoi akademii khudozhestv za sto liet eia sushchestvovaniia (St. Petersburg, 1864-66), 2:324, 345; Portrety A. V. Suvorova: Ocherki ikonografii (Leningrad, 1963), 103-7.
} 
the "cause of our [country's] renaissance," a depiction of the "sacred relics of Imperial Russia" (sviatyni Rossii) itself. ${ }^{59}$

To make this historically accurate depiction of Russia's "sacred relics" even more widely available to those "connoisseurs of fine art" who could not visit his studio on the Fontanka, Frosté authorized a Parisian print-maker to create an "engraving à l'acquatinte," which could then be purchased from retailers in St. Petersburg and Moscow or ordered by subscription. This engraving appeared in three different impressions, the last of which bore a fawning dedication to "His Imperial Highness, the Sovereign Heir-Apparent, Tsarevich, and Grand Prince Aleksandr Nikolaevich" (the future Alexander II), who acknowledged the artist's efforts by presenting him with an "expensive diamond ring." ${ }^{\circ 60} \mathrm{In}$ 1841 a small, steel-engraved print based on Frostés aquatint even found its way onto the pages of Utrenniaia zaria, an illustrated Russian almanac published by the Third Section of Nicholas I's personal chancellery and edited by one of its loyal employees, Col. V. A. Vladislavlev (plate 12). Vladislavlev placed Frosté's Peter between the pages of a poem called "The Royal Flower Garden: An Historical Tale," which was written by the minor Romantic poet P. G. Obodovskii. ${ }^{61}$ Obodovskii's quasi-folkloric, mawkishly sentimental, and thinly disguised allegory evoked the "family grove" of birch trees planted in Pavlovsk on the orders of Paul's widow, the Dowager-Empress Mariia Fedorovna, who was central to early nineteenth-century efforts to create an image of the dynasty as moral model. All of the trees in the Pavlovsk family grove "were dedicated to each member of the family, and each had a place with his or her name, birth date, and in some cases the date of marriage." Similarly, in Obodovskii's poem each member of the household of the currently reigning emperor was represented as a different type of flowering plant in an edenic, northern garden: Nicholas I, the "divinely planted," towering "cedar tree," rooted firmly in native Russian soil; his adoring, "lily white" wife; their three "rosy" daughters and three manly sons ("cedar buds"); the heir-apparent, a "cedar sprout" as majestic and "as firmly rooted" as its original; and his foreign-born wife, an exotic, imported flower, "raised under foreign skies" but quickly "clasped to Russia's bosom." The royal flower garden, meanwhile, was situated near the "waters of mirror-smooth seas,/ on which playfully flew/ the flags of Peter's ships." This explicit reference to Peter the Great, whom Nicholas I worshiped, seems to have informed Vladislavlev's choice of appropriate illustrative material. ${ }^{64}$ In this way, Frosté's rather pedestrian nod to existing Petrine iconography — a nod fully in keeping with conventional Romantic treatments of Peter as the self-effacing, hard-working carpenter

\footnotetext{
59“"Portret Petra Velikogo," Severnaia pchela 32 (February 9, 1840): [125]; V. P., "Izobrazhenie Petra Velikogo," Syn otechestva 3 (1840): 555; and Syn otechestva 1 (1840): 479.

${ }^{60}$ Severnaia pchela 32 (February 9, 1840):125; Rovinskii, Podrobnyi slovar' russkikh gravirovannykh portretov 3:1631; and V. V. Stasov, Gallereia Petra Velikago v Imperatorskoi publichnoi bibliotekie (St. Petersburg, 1903), 1:41.

${ }^{61}$ P. G. Obodovskii, “Tsarskii tsvetnik: Byl'," Utrenniaia zaria (1841): 1-8. H. Robinson's engraving of Frosté's Peter the Great is found between pages 2 and 3.

${ }^{62}$ Richard Wortman, Scenarios of Power: Myth and Ceremony in Russian Monarchy, 2 vols. (Princeton, 1995, 2000), 1:250.

${ }^{63}$ Obodovskii, "Tsarskii tsvetnik," 6.

${ }^{64}$ On Nicholas' attitude to Peter see Wortman, Scenarios of Power 1:301-2, 305, 348, 371, 379-80, 405, 409; and Nicholas V. Riasanovsky, The Image of Peter the Great in Russian History and Thought (New York, 1985), 107-8.
} 
tsar-was integrated into the reigning "dynastic scenario," which extolled the wholesomeness of the Russian Imperial family and hailed Mariia Fedorovna's son as a new Father of the Fatherland..$^{65}$

It is all the more significant, then, that the creators of the NYPL series chose this same "iconic" depiction of Russia's founding father as the basis for the first watercolor in their royal rogues' gallery (plate 1). The anonymous draftsman repeated most of the elements found in Frosté's portrait, including such "sacred relics" as Peter's uniform, sash, and tricorn hat, the ship model and shipbuilding instruments, and the work bench. Significantly, he substituted a half-nude woman for the unrolled map of St. Petersburg and replaced the marine painting over Peter's left shoulder with a picture window, possibly in order to make it more congruent with the theme of voyeurism implicit in Chuvaev's "An Impediment to Love," to which it bears an uncanny resemblance. More important, by depicting the royal phallus in action he literally exposed the hidden, sexual dimension in the contemporary eroticization of autocratic potency, thereby pointedly de-Romanticizing the sentimental idyll presented in "The Royal Garden." the Imperial "family grove" back to its roots in the eighteenth century, a time when the boundaries between the private and public spheres, at least at court, were defined in a way that violated nineteenth-century conceptions of "bourgeois respectability." ${ }^{967}$ From the perspective afforded by this alternative vision of the Romanov family tree, the series of erotic watercolors presented a tale about the withering, rather than the flowering, of the House of Romanov-a narrative of historical decline, at once moral, sexual, and political, from virile Peter to passive Paul, by way of a string of increasingly more assertive female partners, the last one of whom appears completely naked, sitting astride her lover as if on a horse. The fact that the woman in this illicit (because nonprocreative) sexual position was supposed to represent none other than the "Mother of the Dynasty" only added insult to the injury inflicted by this "sacrilegious" attack on the Imperial cult of Russia's founding father. ${ }^{68}$

The counter-scenario presented by the creators of the NYPL series travestied Romanov pretensions to dynastic virtue by depicting the Dowager-Empress as the very epitome of the carnivalesque trope of "women on top." ${ }^{69}$ In this symbolic capacity, she served as the antithesis to the masculine rule of the "sainted" Peter and Paul, one of whom proclaimed himself Russia's emperor and symbolically fathered the Fatherland, and the other who formally codified male primogeniture within the royal family and actually fathered ten children (including Alexander I and Nicholas I) ${ }^{70}$ The creators of the watercolors may

${ }^{65}$ Wortman, Scenarios of Power 1:247-417, esp. 247-49.

${ }^{66}$ For an insightful discussion of the Romantic eroticization of the tsar, as well as its subversion, see Mikhail Vaiskopf, "Brak s vlastelinom: Eroticheskie aspekty derzhavnoi ritoriki," Novoe literaturnoe obozrenie 6 (2009): 77-88; and Katharine Holt, "The Gavriliada as Gossip," Ulbandus Review 12 (2009/2010): 1-20.

${ }^{67}$ Dixon, "Posthumous Reputation of Catherine," 667, 676; idem, "Catherine the Great and the Romanov Dynasty: The Case of the Grand Duchess Mariia Pavlovna (1854-1920)," in Russian Society and Culture and the Long Eighteenth Century: Essays in Honor of Anthony G. Cross, ed. Roger Bartlett and Lindsey Hughes (Münster, 2004), 199-200.

${ }^{68}$ On Russian "mother curses" (maternaia bran') see Igor Kon, The Sexual Revolution in Russia: From the Age of the Czars to Today, trans. James Riordan (New York, 1995), 282-83.

${ }^{69}$ Natalie Zeman Davis, Society and Culture in Early Modern France (Stanford, 1975), 114-51.

${ }^{70}$ Wortman, Scenarios of Power 1:176-78. 
even have sought to resurrect scurrilous rumors about Mariia Fedorovna's behavior in the days immediately after Paul's murder, when the emperor's German-born consort supposedly demanded that she be allowed to rule in her own right ("Ich will regieren!"), an allegation recorded in the memoirs of one political émigré (the Decembrist M. A. Turgenev) and publicized in the writings of another (Prince P. V. Dolgorukov). ${ }^{71}$ This libelous assertion may help to explain why the anonymous draftsman of the erotic watercolors presented the otherwise nude figure of Mariia Fedorovna in red-heeled shoes known as talons rouges, a piece of fashionable eighteenth-century footwear that was associated with royalty and "futile insolence," and that had even appeared in the title of a 1780 pamphlet attacking MarieAntoinette. ${ }^{72}$ In effect, by casting doubt on the morals of the Dowager-Empress, the creators of the NYPL series sought to impugn both the spiritual and actual paternity of Paul's children, and thereby to suggest that the currently reigning monarch was in reality a "Russian German"- a false tsar who had no right to pass himself off either as a Romanov or as the legitimate ruler of Imperial Russia. ${ }^{73}$

\section{DEFACEMENT}

The NYPL series' ineluctable slide from Peter to Paul and, by implication, to "Paul's progeny" (Pavlovo otrod'e), offered a graphic illustration of the classical truism that political degeneration is a concomitant of the general decline of morals. ${ }^{74}$ This argument was reiterated most forcefully at the end of the eighteenth century in Edward Gibbon's The History of the Decline and Fall of the Roman Empire, which many Russians read in a French translation that equated "decline" with "decadence." 75 In Russia itself, the notion of imperial decadence had most famously been invoked by Prince Mikhail Shcherbatov in his 1787 polemic, On the Decline of Morals in Russia, which circulated in manuscript among members of his family, among whom, it must be remembered, was not only the critic Peter Chaadaev but also several members of the failed conspiracy to overthrow the Russian monarchy in December $1825 .{ }^{76}$ This notion was also implicit in Pushkin's unpublished 1822 essay about Peter's "mediocre successors," who sought to re-create the emperor's arbitrary, allencompassing, oppressive form of autocracy (svoevlastie), but succeeded only in fostering

${ }^{71}$ See P. V. Dolgorukov, Peterburgskie ocherki: Pamflety emigranta, 1860-1867 (Moscow, 1992), 257, 461-62.

${ }^{72}$ Philip Mansel, Dressed to Rule: Royal and Court Costume from Louis XIV to Elizabeth II (New Haven, 2005), 15. Thanks to Hilde Hoogenboom for bringing this reference to my attention.

${ }^{73}$ The title of an "agitational" song composed in 1823 by the Decembrists A. A. Bestuzhev and K. F. Ryleev, "Nash tsar'—nemets russkii [1823]," in Vol'naia russkaia poeziia XVIII-XIX vekov, 278-79; and Iu. G. Oksman, “Agitatsionnaia pesnia 'Tsar' nash-nemets russkii,"” Literaturnoe nasledstvo 59 (1954): 71-72.

${ }^{74}$ Dolgorukov, Peterburgskie ocherki, 234 n.2, 461-62, 257 n.1.

${ }^{75}$ Edward Gibbon, The History of the Decline and Fall of the Roman Empire, 6 vols. (London, 1776-88). Histoire de la décadence et de la chute de l'empire Romain went through several editions (1777, 1788-95, 1812, 1828, 1837-38, etc.); the 1828 edition was found in Pushkin's personal library. See B. L. Modzalevskii, Biblioteka A. S. Pushkina: Bibliograficheskoe opisanie (Moscow, 1988 [St. Petersburg, 1910]), 239.

${ }^{76}$ See N. Ia. Eidel'man's commentary to the facsimile edition of Herzen's O povrezhdenii nravov $v$ Rossii kniazia M. Shcherbatova i Puteshestvie A. Radishcheva: Faksimial'noe izdanie, ed. M. V. Nechkina et al. (Moscow, 1984), 26-27. 
an atmosphere of "Oriental ignorance at court." According to Pushkin, this Oriental ignorance was attested to by the "reigns" of the "illiterate Catherine I," the "bloody villain Biron," the "voluptuous Elizabeth," and the "lusty Catherine II ... a corrupt empress who corrupted her realm." From this brief and highly critical survey of Imperial Russian history, Pushkin drew the conclusion that the enlightenment begun under Peter's oppressive tutelage inexorably led to the need for political liberation (that is, constitutionalism), "which is now necessarily linked to the emancipation of the serfs"-a political position consonant with that of his friends, the future Decembrists, and their later followers and admirers. ${ }^{77}$

As is well known, one of the Decembrists' most ardent admirers was none other than Alexander Herzen, a political émigré and self-described socialist, whose revolutionary activity included the publication of damning documentation about the "secret history" of the Romanov dynasty. ${ }^{78}$ With the help of a group of "correspondents" from Moscow and St. Petersburg, Herzen's London-based "Free Russian Press" printed not only Shcherbatov's "severe critique of court debauchery," but also several other uncensored, politically sensitive, and previously unpublished primary sources, including the explosive Memoirs of Catherine the Great. ${ }^{79}$ Herzen's sexually charged polemical introductions to these publications demonstrate the extent to which his take on the characters in the drama of imperial degeneration - a nightly performance that was staged behind a "triple line of sentinels ... in the gloom of the alcove" and that included "scenes worthy of Shakespeare, Tacitus, and Barkov" - was indebted to an already well-established tradition of underground, manuscript literature, which condemned the ruling dynasty for moral decay caused by foreignness, favoritism, and female rule. ${ }^{80}$ As I have suggested, this was the very same underground tradition that served as the source of the graphic and literary images employed by the anonymous individuals who created the series of "double drawings" under discussion. Like Herzen, the creators of the NYPL series straddled the fine line between invoking the specter of female rule to mock the reigning representative of the House of Romanov while simultaneously holding tight to an elite Russian man's privileged position of being able to objectify women for his own purposes. The fact that in both cases the overarching historical narrative remained a standard, heterosexual, phallocentric story of men penetrating women, suggests both the extent and the limits of perversity in the political imagination of their creators.

While this "priapism of the imagination" can hardly qualify as an example of revolutionary politics, the series of anonymous erotic watercolors under discussion was

${ }^{77}$ Pushkin, "[Zametki po russkoi istorii XVIII veka]," 14-17.

${ }^{78}$ N. Ia. Eidel'man, "Vosemnadtsatoe stoletie v izdaniiakh Vol'noi Russkoi Tipografii," in Spravochnyi tom k zapiskam E. R. Dashkovoi, Ekateriny II, I. V. Lopukhina, ed. E. L. Rudnitskaia (Moscow, 1992), 155-250. Also see his Tainye korrespondenty "Poliarnoi zvezdy" (Moscow, 1966); and his Gertsen protiv samoderzhaviia: Sekretnaia politicheskaia istoriia Rossii XVIII-XIX vv. i Vol'naia pechat' (Moscow, 1973).

${ }^{79}$ Herzen's characterization of Shcherbatov's work in O povrezhdenii nravov v Rossii, xii. See also Memoirs of the Empress Catherine II., written by herself, with a preface by A. Herzen. Tr. from the French (New York, 1859), 3-16, published simultaneously in French and German. For the book's publication history see the introduction to The Memoirs of Catherine the Great, trans. Mark Cruse and Hilde Hoogenboom (New York, 2005).

${ }^{80}$ Memoirs of the Empress Catherine II, 14-15; Gertsen, O povrezhdenii nravov v Rossii, ix. 
clearly much more than a source of sexual titillation. ${ }^{81}$ For in graphically depicting the "family jewels" of the royals and their favorites, the album drawings laid bare what their creators believed were the actual arcana imperiii and thereby articulated, in the most provocative way possible, the argument that sex and favoritism, not Orthodoxy and nationality, underlay the Romanov dynasty's claim to rule over the Russian people. ${ }^{82}$ This shocking (and humorous) juxtaposition of the face and the genitals quite literally enacted the notion of "defacement." "In so doing, it deliberately implicated the album's select, and almost certainly elite, male audience in the illicit pleasure of exposing the "official secret"a secret that "is known to everyone" but that cannot be discussed in public. ${ }^{84}$ In the case of the NYPL series, the "official secret" in question was the contested legitimacy of the Russian ruling dynasty in an age of incipient nationalism. And the act of defacement was an audacious attempt to transform a set of scandalous historical anecdotes about members of the Russian royal family into an illustrated, full-frontal history of the House of Romanov.

81"Priapizm voobrazheniia" is how Viazemskii characterized Pushkin's bawdy poem "Graf Nulin" (1825), which he read in manuscript (P. A. Viazemskii, Zapisnye knizhki: 1813-1848, ed. V. S. Nechaeva [Moscow, 1963], 72, 396 n.178).

82“"Orthodoxy, Autocracy, and Nationality," the unofficial motto of the Nicholaevan regime, was formulated in 1833 by Sergei Uvarov, the Minister of Education. See Nicholas V. Riasanovsky, Nicholas I and Official Nationality in Russia, 1825-1855 (Berkeley, 1959).

${ }^{83}$ On "defacement" as the "equivalent of covering the genitals" see Michael Taussig, Defacement: Public Secrecy and the Labor of the Negative (Stanford, 1999), 25-26, 36-38.

${ }^{84}$ Dolgorukov, Peterburgskie ocherki, 118, 128. 